\title{
The Potential Therapeutic Effect of RNA Interference and Natural Products on COVID-19: A Review of the Coronaviruses Infection
}

\begin{abstract}
Mohammad Reza Kalhori ${ }^{1}$, Fatemeh Saadatpour ${ }^{2}$, Ehsan Arefian ${ }^{2}$, Masoud Soleimani ${ }^{3}$, Mohammad Hosien Farzaei ${ }^{4 *}$, Ina Yosifova Aneva ${ }^{5}$ and Javier Echeverría ${ }^{6 *}$

${ }^{1}$ Medical Biology Research Center, Health Technology Institute, Kermanshah University of Medical Sciences, Kermanshah, Iran, ${ }^{2}$ Molecular Virology Lab, Department of Microbiology, School of Biology, College of Science, University of Tehran, Tehran, Iran, ${ }^{3}$ Department of Hematology, Faculty of Medical Sciences, Tarbiat Modares University, Tehran, Iran, ${ }^{4}$ Medical Technology Research Center, Health Technology Institute, Kermanshah University of Medical Sciences, Kermanshah, Iran, ${ }^{5}$ Institute of Biodiversity and Ecosystem Research, Bulgarian Academy of Sciences, Sofia, Bulgaria, ${ }^{6}$ Departamento de Ciencias del Ambiente, Facultad de Química y Biología, Universidad de Santiago de Chile, Santiago, Chile
\end{abstract}

The SARS-CoV-2 virus was reported for the first time in Wuhan, Hubei Province, China, and causes respiratory infection. This pandemic pneumonia killed about 1,437,835 people out of $61,308,161$ cases up to November 27, 2020. The disease's main clinical complications include fever, recurrent coughing, shortness of breath, acute respiratory syndrome, and failure of vital organs that could lead to death. It has been shown that natural compounds with antioxidant, anticancer, and antiviral activities and RNA interference agents could play an essential role in preventing or treating coronavirus infection by inhibiting the expression of crucial virus genes. This study aims to introduce a summary of coronavirus's genetic and morphological structure and determine the role of miRNAs, siRNAs, chemical drugs, and natural compounds in stimulating the immune system or inhibiting the virus's structural and non-structural genes that are essential for replication and infection of SARS-CoV-2.

Keywords: coronavirus, miRNA, siRNA, natural products, phytochemicals, SARS-CoV-2

\section{INTRODUCTION}

Over the past 50 years, a wide range of human and animal diseases have been caused by coronaviruses (CoVs). Since the emergence of Severe Acute Respiratory Syndrome (SARS-CoV) Coronavirus in 2003, a considerable number of new Human coronaviruses (H-CoVs) have been identified (Ding et al., 2003). The appearance of Middle East Respiratory Syndrome (MERS-CoV) coronavirus in 2012 and the continuous occurrence of human cases further intensified attention to the importance of studying these viruses from different aspects (Centers for Disease Control and Prevention, 2012). Tolerance of new mutations and recombination has led to the evolution of this group of viruses, giving them the ability to transmit between species. In most cases, CoV infections are self-limiting, and after completing a reasonable period, the body recovers from the illness (Enjuanes et al., 2000). However, some strains of this family cause severe infections and have been the cause of widely spread epidemics during the last two decades (Mahase, 2020).

The SARS-CoV-2 virus was reported for the first time in Wuhan, Hubei Province, China, and causes respiratory infection. According to WHO statistics, on November 27, 2020, Coronavirus 
disease 2019 (COVID-19) killed about 1,437,835 people out of $61,308,161$ cases, and the most significant number of deaths and infected people were in the Americas (Chen et al., 2020b). In recent years, many treatment strategies such as prescribing antibiotics, the application of antiviral drugs (including Human Immunodeficiency Virus 1 (HIV-1) protease inhibitors, oseltamivir, and ribavirin), different corticosteroids, interferons, and natural human immunoglobulin have been used for treating patients suffering from H-COVs. Recently, most treatment strategies for CoVs such as MERS-CoV, SARS$\mathrm{CoV}$, and Severe Acute Respiratory Syndrome coronavirus-2 (SARS-CoV-2) have been based on inhibiting viral agents involved in the replication, infection, or induction of host immune system agents to combat viral infection ( $\mathrm{Li}$ and $\mathrm{De}$ Clercq, 2020; Prajapat et al., 2020). Numerous studies are being conducted today to prove the role of various biomolecules, including RNA interference (RNAi), fusion inhibitors, neutralizing antibodies, plant, or microbial metabolites, as antiviral compounds (Prajapat et al., 2020).

This review article tries to present some information about the biology, replication, infusion, and pathogenesis of coronavirus. Also, it has decided to explain the existing treatment strategies based on chemical drugs, natural compounds, small interfering RNA (siRNAs), and microRNA (miRNAs) that can be used to fight against coronavirus infection, especially SARS-CoV-2. For this purpose, keywords including natural product, flavonoid, polyphenols, phytochemicals, microRNA, siRNA, Coronavirus, COVID-19 up to August 2020 were searched and evaluated using Scopus, PubMed, WOS, and Google Scholar databases.

\section{CORONAVIRUS}

\section{Coronavirus Classification and Taxonomy}

Genome organization, genome homology, reproduction strategies in a host, and the virion's structural traits are criteria for CoVs classification by the International Committee for Taxonomy of Viruses (ICTV) (Casals et al., 1980). In terms of phylogenetics, CoVs belong to Coronaviridae, as the class of Nidovirals. Coronaviridae family includes two sub-families: Orthocoronavirinae and Torovirinae. The sub-family of Orthocoronavirinae consists of four genera: Alpha, Beta, Gamma, and Delta coronaviruses that are responsible for infection on a vast range of hosts, from mammalians to birds (King et al., 2012). Human infection with CoVs was first reported in 1965 (Hamre and Procknow, 1966). $\mathrm{H}-\mathrm{CoV} 229 \mathrm{E}$ and CoV-NL63 are human pathogens of the genus Alpha-CoV, causing common cold (Mcintosh et al., 1970; Monto, 1974). Severe Acute Respiratory Syndrome Coronavirus 1 (SARS-CoV-1), MERS-CoV, and SARS-CoV-2 are phylogenetically classified in the Beta-CoVs genus and have caused a high percentage of mortality in the human population during the last two decades (Zhou et al., 2020). The most common CoVs genes used for phylogenetic studies are nsp12 (RNA dependent RNA polymerase), nsp5 (chymotrypsin-like protease), nsp13 (helicase), nucleocapsid (N), and spike protein (S) (ICTV, 2009).

\section{Genomic Structure}

CoVs are positive single-strand RNA with $32-46 \% \mathrm{G}+\mathrm{C}$ content. They have the biggest genome size among all known RNA viruses (about 26.4-31.7 kb) (Lai and Cavanagh, 1997; Enjuanes et al., 2000). Depending on the strain, the genome in CoVs contains a different number of open reading frames (ORF). Nevertheless, ORF1a, ORFb1, envelope (E), protein $\mathrm{S}$, protein $\mathrm{N}$, and membrane protein $(\mathrm{M})$ are present in all Human-CoV strains (Cavanagh, 1995; Enjuanes et al., 2000). The SARS-CoV-2 genome size varies from 29.8 to $29.9 \mathrm{~kb}$ and encodes 9,860 amino acids. The ORF1ab in SARS-CoV-2 is over $21 \mathrm{~KB}$ in length and covers two-thirds of the entire genome (Cascella et al., 2020). According to recent reports, the ORF portion of the SARS-CoV-2 genome has a lower CG dinucleotide percentage than other coronaviruses, so ORF RNA translation is highly efficient (Wang Y. et al., 2020).

\section{Coronavirus Replication Process}

The replication cycle of CoVs occurs in several stages (Figure 1). In the initial stage, the virus binding proteins are attached to appropriate receptors on the host cell's surface. Then membrane fusion occurs, which finally leads to virus genome insertion in the host cell. In the second step, the RNA polymerase-dependent RNA gene is activated to translate the virus genome into structural proteins (Ziebuhr, 2005). During these steps, in addition to viral factors, some host cell factors can also enhance or inhibit this process.

\section{Attachment; Entry and Cellular Factors Involvement}

The first stage of virus entry starts with the attachment of $S$ proteins to host ligands. Most HCoVs use endocytosis pathways for their entrance, while others can use direct membrane fusion (Gallagher and Buchmeier, 2001). The ectodomain S protein consists of a receptor-binding subunit (S1) and a membrane subunit (S2). After binding to the host cell surface receptors, the S1 subunit leads to a structural change in S2. The S2 proteolytic domain then fuses the virus membrane into the host membrane, leading to the viral genome's entry into the host cell. A partial mutation in the $S$ protein that changes the amino acid sequence can significantly affect the virus's pathogenesis and tissue or cell susceptibility to infection (Li, 2016).

HCoV-NL63, SARS-CoV, and SARS-CoV-2, use AngiotensinConverting Enzyme 2 (ACE2) to contaminate cells (Moore et al., 2004; Zhang et al., 2020a). Both types of alveolar cells (I and II types) and the endothelial cells express ACE2. It has been shown that MERS-CoV uses Dipeptidyl peptidase 4 (DPP4), a physiological ligand for adenosine deaminase, which is extensively expressed by the endothelial cells in various tissues (Raj et al., 2013). However, many host factors can limit the entry of the virus. According to cell culture mechanisms, a family of Interferon-Inducible Transmembrane proteins (IFITM) could limit S protein-dependent access in $\mathrm{HCoV}-229 \mathrm{E}$ and $\mathrm{HCoV}$ NL63, which would also lead to intense reduction of the infection in SARS-CoV and MERS-CoV (Huang et al., 2011; Wrensch et al., 2014). It seems that IFITM inhibits the membrane fusion by 


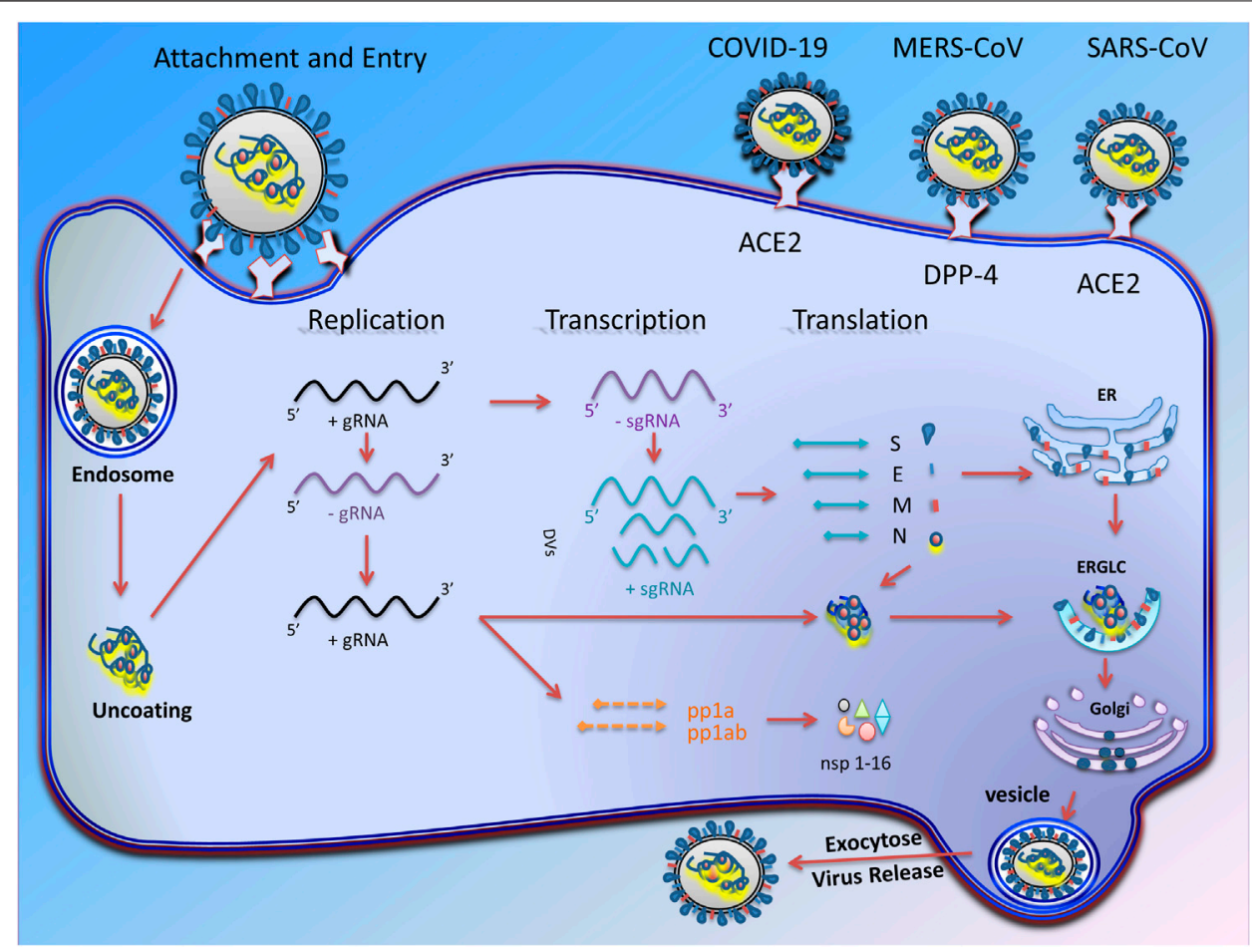

FIGURE 1 | Transcription and replication of coronavirus. Schematic picture showing the coronavirus infection starts with attachment of virus $S$ proteins to receptors on the host cells. After successful fusion, ribonucleocapsid enters the cell cytoplasm and loses its coat to mRNA is released. RNA-dependent RNA synthesis in CoVs includes two different genome replication processes to achieve multiple copies of genomic RNAs (gRNAs) and transcription of sub-genomic RNAs (sg mRNAs) coding structural and accessory proteins. The gRNA eventually producing 16 non-structural proteins (nsp-16) that are involved in virus replication. After assembly and budding, the full virus particles are transferred to the cytoplasmic membrane and finally released through the exocytosis process.

preventing the virus fusion to the cell membrane, endosomal membranes, or through membrane fluidity. Moreover, it was shown that human coronavirus HCoV-OC43 utilizes IFITM2 and IFITM3 as receptors to facilitate cell entry (Zhao et al., 2014).

\section{Transcription and Replication}

In CoVs, RNA-dependent RNA polymerase amplifies the virus genome in two ways and eventually produces several copies of genomic RNAs (gRNAs) and subgenomic RNAs (sg mRNAs) (Ziebuhr, 2005). Generally, CoVs replication is initiated with the translation of ORF1a to produce polyprotein1a (pp1a) with 4,382 amino acids and polyprotein $1 \mathrm{ab}$ (pplab) with 7,073 amino acids. Then, the ORF1b is translated through the ribosomal frameshifting mechanism (Lai, 1990; Ziebuhr, 2005). Eventually, each of these polyproteins is cleaved to produce 16 non-structural proteins (nsp16), which are involved in the virus replication cycle (Mcintosh and Peiris, 2009). Some of the non-structural proteins (Table 1) that have critical roles in the virus's life cycle include helicase (nsp13), RNA-dependent RNA polymerase (RdRP) (nsp12 polymerase), 3chymotripsin-like protease (3CL ${ }^{\text {pro }}$ ) (nsp5 protease), and papainlike protease (PL ${ }^{\text {pro }}$ ) (nsp3 protease) (Lai, 1990; Sawicki et al., 2005).

\section{Virus Assembly and Egress}

The structural proteins (Table 2) and some membrane accessory proteins are translated inside ER-bound ribosomes, while $\mathrm{N}$ protein is translated via free ribosomes in the cytoplasm (Nal et al., 2005). One of the distinct characteristics of CoVs is virion aggregation inside the ER and budding toward the Golgi apparatus (Cawood et al., 2007). Moreover, E, S, and N proteins interpolation to virions is modulated by $\mathrm{M}$ protein heterotypic interaction in the budding locus (Opstelten et al., 1995). After assembly and budding, the full virus particles are transferred to the cytoplasmic membrane and finally are released through the exocytosis process (Figure 1).

\section{Coronaviruses Pathogenesis}

Clinically, the pathogenesis of coronaviruses is divided into three stages. In the viremia phase, the virus enters the peripheral blood after the lungs are infected. Thus, the virus can reach its target tissues, such as the heart, kidneys, and gastrointestinal tract, through the bloodstream. The second phase is the pneumonia phase. Then the patient enters the recovery phase if the immune system can overcome the virus's attack at this stage. However, in patients with immunodeficiency, high blood pressure, diabetes, and the elderly, the immune system cannot effectively manage the infection, and a critical stage of the disease occurs (Peiris et al., 2003; Guan et al., 2020).

\section{TREATMENT}

Vaccination is the best way to control the COVID-19 pandemic, and many efforts are being made to produce it. Nevertheless, its 
TABLE 1 | Biological activities of coronavirus non-structural proteins.

\begin{tabular}{|c|c|c|c|}
\hline Proteins & $\begin{array}{l}\text { Biological functions in } \\
\text { virus particle }\end{array}$ & $\begin{array}{l}\text { Effect on the } \\
\text { host cellular response }\end{array}$ & Refs. \\
\hline Nsp1 & $\begin{array}{l}\text { A virulence factor. } \\
\text { The genus-specific marker. } \\
\text { Highly divergent among CoVs }\end{array}$ & $\begin{array}{l}\text { Interact with the } 40 \mathrm{~S} \text { subunit of ribosome to prevent host mRNA } \\
\text { translation. }\end{array}$ & Woo et al. (2010) \\
\hline Nsp2 & Not reported. & $\begin{array}{l}\text { Interaction with two host proteins, PHB1 and PHB2 and disruption } \\
\text { of intracellular host cell surviving signaling pathway. }\end{array}$ & $\begin{array}{l}\text { Cornillez-Ty et al. } \\
\text { (2009) }\end{array}$ \\
\hline \multirow[t]{2}{*}{ Nsp3 } & $\begin{array}{l}\text { Cysteine-type endopeptidase activity at the } \mathrm{N} \text {-terminus of the } \\
\text { replicase polyprotein. }\end{array}$ & $\begin{array}{l}\text { Plays a role in host membrane rearrangement. Downregulate } \\
\text { mRNA levels of pro-inflammatory cytokines including CCL5, and } \\
\text { CXCL10. }\end{array}$ & Lei et al. (2018) \\
\hline & $\begin{array}{l}\text { Nucleic acid binding by interaction with N protein, RNA-directed } 5^{\prime}-3^{\prime} \\
\text { RNA-directed } 5^{\prime}-3^{\prime} \text { RNA polymerase activity. }\end{array}$ & $\begin{array}{l}\text { Responsible for suppressing IFN induction. Antagonize IFN } \\
\text { production }\end{array}$ & \\
\hline Nsp4 & $\begin{array}{l}\text { Marker for the coronavirus-induced DMVs. } \\
\text { Interacts with nsp3 and nsp6 to formation of the replication } \\
\text { complexes. }\end{array}$ & Not reported. & $\begin{array}{l}\text { Angelini et al. } \\
\text { (2013) }\end{array}$ \\
\hline Nsp5 & Cleaves the C-terminus of replicase polyprotein at 11 sites & $\begin{array}{l}\text { Bind an ADRP, may cleave host ATP6V1G1 and modifying host } \\
\text { vacuoles intracellular } \mathrm{pH}\end{array}$ & Lin et al. (2005) \\
\hline \multirow[t]{2}{*}{ Nsp6 } & Necessary for viral replication. & $\begin{array}{l}\text { Plays a role in the initial induction of autophagosomes from host } \\
\text { reticulum endoplasmic. }\end{array}$ & $\begin{array}{l}\text { Angelini et al. } \\
(2014)\end{array}$ \\
\hline & Mediates the DMV formation by rearrangement of host membrane. & $\begin{array}{l}\text { Limits the expansion of these phagosomes that are no longer able } \\
\text { to deliver viral components to lysosomes. }\end{array}$ & \\
\hline Nsp7 & $\begin{array}{l}\text { A primase in the form of heterohexadecamer dsRNA-encircling as } \\
\text { ring structure. }\end{array}$ & Not reported. & $\begin{array}{l}\text { Te Velthuis et al. } \\
\text { (2012) }\end{array}$ \\
\hline Nsp8 & A processivity factor for the RdRP. & & \\
\hline Nsp9 & $\begin{array}{l}\text { May participate in viral replication by acting as a ssRNA-binding } \\
\text { protein. }\end{array}$ & Not reported. & Miknis et al. (2009) \\
\hline Nsp10 & $\begin{array}{l}\text { Interact with nsp1, nsp7, nsp } 14 \text {, and nsp16. } \\
\text { Implicated in the regulation of polyprotein processing. Plays a pivotal } \\
\text { role in viral transcription by stimulating both nsp } 143^{\prime}-5^{\prime} \\
\text { exoribonuclease, and nsp16 } 2^{\prime}-O \text {-methyltransferase activities }\end{array}$ & Not reported. & $\begin{array}{l}\text { Bouvet et al. } \\
(2012)\end{array}$ \\
\hline Nsp12 & $\begin{array}{l}\text { Responsible for replication and transcription of the viral RNA } \\
\text { genome. }\end{array}$ & Not reported. & Ahn et al. (2012) \\
\hline Nsp13 & $\begin{array}{l}\text { Magnesium dependent helicase activity. } \\
\text { Displaying RNA and DNA duplex-unwinding activities with } 5^{\prime} \text { to } 3^{\prime} \\
\text { polarity. }\end{array}$ & Not reported. & $\begin{array}{l}\text { Tanner et al. } \\
\text { (2003) }\end{array}$ \\
\hline \multirow[t]{2}{*}{ Nsp14 } & $\begin{array}{l}\text { An exoribonuclease acting on both ssRNA and dsRNA in a } 3^{\prime} \text { to } 5^{\prime} \\
\text { direction. }\end{array}$ & Interacts with DDX1 via N-terminus. & $\begin{array}{l}\text { Denison et al. } \\
\text { (2011) }\end{array}$ \\
\hline & Acts as a proofreading exoribonuclease for RNA replication. & Modulation of the innate immune response. & \\
\hline Nsp15 & $\begin{array}{l}\mathrm{Mn}^{2+} \text {-dependent, uridylate-specific enzyme, which leaves } 2^{\prime}-3^{\prime}- \\
\text { cyclic phosphates } 5^{\prime} \text { to the cleaved bond. }\end{array}$ & Essential to evade dsRNA sensors. & $\begin{array}{l}\text { Ricagno et al., } \\
\text { 2006) }\end{array}$ \\
\hline Nsp16 & $\begin{array}{l}\text { Mediates mRNA cap } 2^{\prime} \text {-O-ribose methylation to the } 5^{\prime} \text {-cap structure } \\
\text { of viral mRNAs. }\end{array}$ & $\begin{array}{l}\text { Essential to evade MDA5 recognition. } \\
\text { Negatively regulating innate immunity. } \\
\text { IFN antagonism. }\end{array}$ & $\begin{array}{l}\text { Bouvet et al. } \\
(2010)\end{array}$ \\
\hline
\end{tabular}

production is time-consuming because it must first be proven to be immunogenic and effective. Therefore, prevention is currently the best treatment. There are two essential strategies for treatment this disease. The first step is a general treatment that reduces the symptoms and clinical complications of the patients, and the second is drug treatment.

\section{General Treatment}

The available treatment options for these patients include measuring and monitoring of vital signs such as heart function, kidney, liver, respiratory rate, and oxygen therapy if necessary. Moreover, patients must be getting enough water, sufficient calories, balance for electrolytes, and use of fever medicines such as acetaminophen and ibuprofen (Wang J. et al., 2020; Zimmermann and Curtis, 2020). Although the use of corticosteroids such as methylprednisolone in the SARS-CoV epidemic has been shown to improve some clinical symptoms, it is not common in COVID-19. Nevertheless, it could be used only temporarily in patients with severe illness such as dyspnea and Acute Respiratory Distress Syndrome (ARDS) (Huang et al., 2020; Russell et al., 2020; Zhang et al., 2020b). Herbal medicines have the property to be used as a dietary supplement for relieving and reduce respiratory symptoms and other symptoms of COVID-19. They can improve the general condition of patients with mild disease severity. Althaea officinalis L. (Malvaceae), Commiphora myrrha (T.Nees) Engl. (Burseraceae), Glycyrrhiza glabra L. (Fabaceae), Hedera helix L. (Araliaceae), and Sambucus nigra L. (Viburnaceae) are some of the herbal medicines can be used as adjunctive therapy for mild COVID-19 (Silveira et al., 2020).

\section{Coronavirus Drug Treatment}

SARS-CoV-2 is a new virus from the Coronaviruses family, with $79 \%$ genomic similarity to SARS-CoV and $51.8 \%$ to MERS-CoV. 
TABLE 2 | The biological functions of structural proteins of SARS and SARS-CoV 2.

\begin{tabular}{|c|c|c|c|c|}
\hline Protein & $\begin{array}{l}\text { Post-translational } \\
\text { modification }\end{array}$ & $\begin{array}{l}\text { Biological functions in } \\
\text { virus particle }\end{array}$ & $\begin{array}{c}\text { Effect on the } \\
\text { host cellular response }\end{array}$ & Refs. \\
\hline S & $\begin{array}{l}\text { Disulfide bridge, Palmitoylation, } \\
\text { N-glycosylation }\end{array}$ & $\begin{array}{l}\text { Virulence factor. } \\
\text { Responsible for recognition of the cellular receptor. } \\
\text { Fusion of virus membrane with host endosome } \\
\text { membrane. }\end{array}$ & $\begin{array}{l}\text { Physically interaction with elF3F. } \\
\text { Modulation the expression of the pro- } \\
\text { inflammatory cytokines IL } 6 \text { and } 8 \text { at a later stage } \\
\text { of infection. }\end{array}$ & $\begin{array}{l}\text { Bosch et al. } \\
\text { (2003) and Nal } \\
\text { et al. (2005) }\end{array}$ \\
\hline M & O-glycosylation, N-glycosylation & $\begin{array}{l}\text { Plays a central role in virus morphogenesis. } \\
\text { Maintain the structure and assembly via its } \\
\text { interactions with other viral proteins such as } 3 \text { a and } \\
7 \mathrm{a} \text {, forms a complex with HE and S proteins. } \\
\text { Promotes membrane curvature, binds to the } \\
\text { nucleocapsid and participates in RNA packaging } \\
\text { into the virus }\end{array}$ & $\begin{array}{l}\text { Suppress IFN I production mediated by RIG-I and } \\
\text { inhibiting the translocation of IRF3 into the } \\
\text { nucleus, IFN antagonism }\end{array}$ & $\begin{array}{l}\text { Nal et al. (2005) } \\
\text { and Siu et al. } \\
(2009)\end{array}$ \\
\hline E & Palmitoylation, glycosylation & $\begin{array}{l}\text { Plays a central role in virus morphogenesis and } \\
\text { assembly. } \\
\text { Responsible for the curvature of the viral envelope. } \\
\text { A virulence factor trafficking within the infected cells } \\
\text { and budding of the virion. }\end{array}$ & $\begin{array}{l}\text { Induction of the cell stress response and } \\
\text { mitochondrial-mediated apoptosis. Disruption of } \\
\text { the lung epithelium, Potential B cell antagonism. }\end{array}$ & $\begin{array}{l}\text { An et al. (1999) } \\
\text { and Liu et al. } \\
\text { (2007) }\end{array}$ \\
\hline $\mathrm{N}$ & $\begin{array}{l}\text { O-glycosylation, ADP- } \\
\text { ribosylation, Sumoylation, } \\
\text { Phosphorylation }\end{array}$ & $\begin{array}{l}\text { An RNA chaperone, associates with the viral } \\
\text { genome in a helical nucleocapsid. } \\
\text { Plays a fundamental role during virion assembly } \\
\text { through its interactions with the viral genome and } \\
\text { membrane protein } \mathrm{M}, \mathrm{E} \text { and nsp3. } \\
\text { Plays an important role in enhancing the efficiency of } \\
\text { sgRNA transcription and viral replication. }\end{array}$ & $\begin{array}{l}\text { Modulate transforming growth factor-beta } \\
\text { signaling by binding host smad3. } \\
\text { Interfere with the function of IRF3. } \\
\text { Inhibition of IFN I response. Induction of } \\
\text { apoptosis. }\end{array}$ & $\begin{array}{l}\text { Zhao et al. (2006) } \\
\text { and Wu et al. } \\
\text { (2009) }\end{array}$ \\
\hline
\end{tabular}

Therefore, since the risk of SARS-CoV-2 vertical infection is the same as these two types of viruses, their treatment can be similar. Consequently, drugs that were previously effective for the treatment of SARS-CoV and MERS-CoV may also have therapeutic potential for the treatment of COVID-19 (Ren et al., 2020). Although a definitive cure for this new virus has not yet been discovered, previous studies suggest that drugs such as western medicines and natural products may have potential efficiency against COVID-19 and could be used to reduce the severity of the disease.

\section{Interferon}

Interferon type $\mathrm{I}$ is a member of the innate immune system produced and secreted in response to viral infections, including alpha and beta-interferon. Interferons exert their antiviral activity in two ways 1) cytotoxic $\mathrm{T}$ lymphocytes and macrophages stimulate the immune system to kill the virus by increasing or stimulating natural killer cells, 2) or inhibit virus replication in the host cell (Samuel, 2001; Sadler and Williams, 2008; Fensterl and Sen, 2009). Previous studies have shown that interferon- $\alpha$, particularly its recombinant form (INF- $a 2 b$ ), can alleviate symptoms and shorten the disease course of respiratory tract viral infections in the early phase (caused by influenza, SARS$\mathrm{CoV}$, and MERS-CoV) through inhibiting virus replication and decreasing the virus load. Therefore, these molecules may be useful in the treatment of COVID-19 (Zheng et al., 2004; Danesh et al., 2011; Falzarano et al., 2013; Khalid et al., 2015). However, according to the latest update (3.2020) of the COVID-19 Treatment Guidelines Panel, there is no comment about its therapeutic effect on COVID-19 (COVID-19 Treatment Guidelines Panel).

\section{Lopinavir/Ritonavir}

Lopinavir/ritonavir is a protease inhibitor that has previously been used against HIV due to its antiviral activity. Nevertheless, later in the SARS-CoV (an epidemic that occurred in 2003), it was discovered that lopinavir/ritonavir by $3 \mathrm{CL}^{\text {pro }}$-inhibitor action could be useful for coronavirus treatment (Chu et al., 2004; Su et al., 2019). Due to the structural similarity of $3 \mathrm{CL}^{\text {pro }}$ in SARSCoV2 and SARS-CoV, previous studies have suggested that this drug may be useful for treating SARS-CoV2 (Uzunova et al., 2020). Nevertheless, later it was found that these drugs do not have the desired effect in treating this infectious disease, and the coronavirus disease 2019 treatment guidelines (last updated: November 3, 2020) announced that its use is not recommended, except in a clinical trial (COVID-19 Treatment Guidelines Panel, 2019).

\section{Ribavirin}

Ribavirin is a nucleoside analog that has antiviral activity. Coadministration of lopinavir/ritonavir has a significant therapeutic effect against SARS-CoV and may reduce ARDS risk (Chu et al., 2004). However, according to the latest update (November 3, 2020) of the COVID-19 Treatment Guidelines Panel, there is no comment about its therapeutic effect on COVID-19 (COVID-19 Treatment Guidelines Panel).

\section{Chloroquine}

Chloroquine is an antiparasitic drug used against malaria, but recently it has been shown to have antiviral activity by blocking virus infection and could suppress SARS-CoV-2 infection in vitro (Wang M. et al., 2020; Colson et al., 2020). Although many physicians and specialists initially considered this drug to treat 
COVID-19, its use is no longer recommended today (COVID-19 Treatment Guidelines Panel).

\section{Favipiravir}

One of the promising drugs in the treatment of COVID-19 is favipiravir. This drug has an inhibitory effect on RNA polymerase, and its early clinical trial showed that not only is the antiviral activity of this drug more significant than lopinavir/ ritonavir, but it has fewer side effects (Cai et al., 2020). However, according to the latest update (November 3,2020) of the COVID19 Treatment Guidelines Panel, there is no comment about its therapeutic effect on COVID-19 (COVID-19 Treatment Guidelines Panel).

\section{Remdesivir}

Remdesivir is one of the drugs that can be used against RNA viruses such as SARS-CoV/MERS-CoV. In vivo and in vitro studies have shown that this adenosine analog by inhibiting RdRP has a therapeutic effect against COVID-19 and could be a choice for treating this new pandemic infectious disease (Holshue et al., 2020; Wang M. et al., 2020). This drug is currently recommended to treat COVID-19 according to the latest update (November 3, 2020) of the COVID-19 Treatment Guidelines Panel (COVID-19 Treatment Guidelines Panel).

\section{Arbidol}

Arbidol is an antiviral compound for prophylaxis and treatment of influenza. An in vitro study has proved that arbidol has a direct antiviral activity on SARS-CoV replication (Wang X. et al., 2020). A clinical trial of this drug on SARS-CoV-2 has also shown that it reduces high flow nasal catheter (HFNC) oxygen therapy, enhances the process of viral clearance and improves focal absorption on radiologic images (Xu et al., 2020a). Arbidol could inhibit host cell adhesion and SARS-CoV-2 spike glycoprotein trimerization. Furthermore, the simultaneous use of arbidol by Lopinavir/ritonavir has a more significant therapeutic effect than the Lopinavir/ritonavir group (Deng et al., 2020). However, according to the latest update (November 3, 2020) of the COVID-19 Treatment Guidelines Panel, there is no comment about its therapeutic effect on COVID-19 (COVID-19 Treatment Guidelines Panel).

\section{Antithrombotic Therapy}

Anticoagulants, like heparins, play a vital role in preventing arterial thromboembolism in patients with heart arrhythmias. One of the leading causes of death in patients with COVID-19 is myocardial and stroke infarction for unknown reasons. Therefore, if hospitalized patients with COVID-19 due to hemophilia or similar diseases do not have anticoagulant contraindications, administration of a prophylactic dose plays a vital role in reducing the complications COVID-19 in patients with symptoms of blood coagulation (such as low levels of antithrombin, increased fibrinogen and di-dimer) (Godino et al., 2020).

\section{Natural Products as Antiviral Agents}

Natural products are biochemical mixtures produced by living organisms in nature The effectiveness of natural compounds in ancient medicine was introduced thousands of years ago (Ji et al., 2009). These compounds, with various pharmacological traits, have antioxidant, anticancer, anti-inflammatory, and antiviral activities. Today, many of the chemical drugs used in medicine are derived from natural compounds (Frabasile et al., 2017). The therapeutic strategy for natural products and chemical drugs is to target the protein molecules needed for each stage of the virus's life cycle (Dias et al., 2012). This section discusses the natural compounds' role in the inhibition of coronavirus infection (Table 3; Figure 2; Figure 3; and Figure 4). It is important to emphasize that within the compounds listed in Table 3, only epigallocatechin-3-gallate (NCT04446065) and resveratrol and zinc picolinate combination therapy (NCT04542993) has been investigated in clinical phase-2 trials against COVID-19 infection.

\section{Targeting S Protein, ACE2, and TMPRSS2 to Inhibit Cell Attachment and Entry}

When a coronavirus enters the host cell, it must first, through its $\mathrm{S}$ protein, bind to the specific receptors at the surface of host cells. The particular receptor for SARS-CoV and SARS-CoV-2 is the ACE2 protein. To reduce the viral entry strength, the expression of the virus $S$ protein can be inhibited or the expression of ACE2 in host cells can be reduced by natural products. Studies have shown that the amino acid sequence of SARS-CoV Spike protein is approximately $76.47 \%$, similar to SARS-CoV-2 (Xu et al., 2020b). Since virus S protein is highly glycosylated, the use of plant-derived lectins, which tend to bind to glycosylated proteins, can prevent the virus from binding to receptors on the cell surface. Previous studies have shown that herbal compounds could be used as inhibitors for the human immune deficiency virus and SARS-CoV feline (Pyrc et al., 2007). Emodin belongs to the anthraquinones compounds (a group of natural compounds), which have anti-inflammatory, anticancer, and antioxidant activities (Izhaki, 2002). In a dose-dependent manner, emodin could significantly inhibit the ACE2 and S protein interaction in the biotinylated Enzyme-Linked Immunosorbent Assay (ELISA) method and Vero E6 cell line. Therefore, we can consider this compound as an antiviral therapeutic agent in the treatment of SARS-CoV (Ho et al., 2007). Some drugs and substances could reduce the expression of the ACE2 receptor. As seen, interleukin4 and interferon- $\gamma$ decreased this receptor in Vero E6 cells (De Lang et al., 2006). Molecular docking and structure-based drug design study reveal that berberine, thebaine, mangiferin, piperine, nimbin, and curcumin have an inhibitory effect against ACE2 receptor and spike glycoprotein of SARS-CoV-2. Among these, curcumin and nimbin have shown the highest interaction with ACE2 receptors and spike glycoprotein than other natural compounds and chemical drugs such as hydroxychloroquine, nafamostat, and captopril (Maurya et al., 2020).

The citrus peel is rich in flavonoid and alkaloid compounds (such as naringin, naringenin, hesperetin, and hesperidin) that play an essential role in maintaining gastrointestinal health and improving the immune system. Naringin is an anti-inflammatory substance that decreases the inflammatory effect in LPS-induced RAW 264.7 macrophages and LPS-treated rats. Therefore, it can inhibit the increase of pro-inflammatory cytokines such as IL-6, 
TABLE 3 | Different types of phytochemicals by their sources and function in the coronavirus infection.

\begin{tabular}{|c|c|c|c|c|c|}
\hline Compound name & $\begin{array}{l}\text { Phytochemical } \\
\text { class }\end{array}$ & Source & Function & $\begin{array}{l}\text { Clinical trial } \\
\text { stage }\end{array}$ & References \\
\hline Baicalein & Flavonoid & $\begin{array}{l}\text { Scutellaria baicalensis Georgi, Scutellaria } \\
\text { lateriflora L. (Lamiaceae) }\end{array}$ & $\begin{array}{l}\text { Inhibit } 3 \mathrm{CL}^{\text {pro }} \text { of SARS-CoV-1 } \\
\text { Decreased the levels of IL- } 1 \beta \text { and } \\
\text { TNF- } \alpha \text { in serum during the SARS- } \\
\text { CoV-2 infection }\end{array}$ & - & $\begin{array}{l}\text { Su et al. (2020) } \\
\text { Song et al. (2020) }\end{array}$ \\
\hline Broussochalcone B & Polyphenol & $\begin{array}{l}\text { Broussonetia papyrifera (L.) L'Hér. ex } \\
\text { Vent. (Moraceae) }\end{array}$ & $\begin{array}{l}\text { Inhibit PL }{ }^{\text {pro }} \text { of SARS-CoV-1 and } \\
\text { MERS-CoV }\end{array}$ & - & Park et al. (2017) \\
\hline Curcumin & Polyphenol & Curcuma longa L. (Zingiberaceae) & $\begin{array}{l}\text { Inhibit the ACE2 receptor and spike } \\
\text { glycoprotein of SARS-CoV-2 }\end{array}$ & - & Maurya et al. (2020). \\
\hline \multirow[t]{2}{*}{ Emodin } & Anthraquinone & Rheum palmatum L. (Polygonaceae) & $\begin{array}{l}\text { Inhibit the interaction of SARS-CoV- } \\
1 \mathrm{~S} \text { protein and ACE2 }\end{array}$ & - & Ho et al. (2007) \\
\hline & & & $\begin{array}{l}\text { Inhibit 3a protein channel of SARS- } \\
\text { CoV-1 }\end{array}$ & - & Schwarz et al. (2011) \\
\hline $\begin{array}{l}\text { Epigallocatechin-3- } \\
\text { gallate }\end{array}$ & Polyphenol & Camellia sinensis (L.) Kuntze (Theaceae) & $\begin{array}{l}\text { Inhibit } 3 \mathrm{CL}^{\text {pro }} \text { of SARS-CoV-1 and } \\
\text { SARS-CoV-2 }\end{array}$ & $\begin{array}{l}\text { Phase } 2 \\
\text { (SARS- } \\
\text { CoV-2) }\end{array}$ & $\begin{array}{l}\text { Jang et al., (2020) and } \\
\text { Nguyen et al. (2012) }\end{array}$ \\
\hline Gallocatechin gallate & Polyphenol & Camellia sinensis (L.) Kuntze (Theaceae) & Inhibit 3CL ${ }^{\text {pro }}$ of SARS-CoV-2 & - & Jang et al. (2020) \\
\hline & & & $\begin{array}{l}\text { Inhibit PL pro and } \mathrm{CL}^{\text {pro }} \text { of SARS- } \\
\text { CoV-1 }\end{array}$ & - & $\begin{array}{l}\text { Nguyen et al. (2012) } \\
\text { and Park et al. (2016) }\end{array}$ \\
\hline Herbacetin & Flavonoid & Linum usitatissimum L. (Linaceae) & $\begin{array}{l}\text { Block the proteolytic activity of SARS- } \\
\text { CoV-2 } 3 \mathrm{CL}^{\text {pro }}\end{array}$ & - & Jo et al. (2020a) \\
\hline Hirsutanonol & Phenol & Alnus glutinosa (L.) Gaertn. (Betulaceae) & $\begin{array}{l}\text { Inhibit PL pro and } 3 \mathrm{CL}^{\text {pro }} \text { of SARS- } \\
\text { CoV-1 }\end{array}$ & - & Park et al., $2012 a$ \\
\hline Hirsutenone & Phenol & $\begin{array}{l}\text { Alnus japonica (Thunb.) Steud. } \\
\text { (Betulaceae) }\end{array}$ & Inhibits PL pro activity of SARS-CoV-1 & - & $\begin{array}{l}\text { Park et al. (2012a) and } \\
\text { Park et al. (2012b) }\end{array}$ \\
\hline lodobananin & $\begin{array}{l}\text { Oligo-oxa- } \\
\text { adamantane }\end{array}$ & Natural product derivative & $\begin{array}{l}\text { Inhibit NTPase/Helicase of SARS- } \\
\text { CoV-1 }\end{array}$ & - & Tanner et al. (2005) \\
\hline Isobavachalcone & Flavonoid & $\begin{array}{l}\text { Cullen corylifolium (L.) Medik. (syn. } \\
\text { Psoralea corylifolia) (Fabaceae) }\end{array}$ & Inhibit PL ${ }^{\text {pro }}$ of SAR-CoV-1 & - & Kim et al. (2014) \\
\hline \multirow[t]{2}{*}{$\begin{array}{l}\text { Kaempferol 3,7- } \\
\text { diglucoside }\end{array}$} & Glycosyloxyflavone & $\begin{array}{l}\text { Asplenium ruta-muraria L., Asplenium } \\
\text { scolopendrium L. (syn. Asplenium }\end{array}$ & $\begin{array}{l}\text { Block virus ion channels in SARS- } \\
\text { CoV-1 }\end{array}$ & - & Schwarz et al. (2014) \\
\hline & & altajense) (Aspleniaceae) & Target SARS-CoV2-S spike protein & - & Pan et al. (2020) \\
\hline Kazinol F & Polyphenol & $\begin{array}{l}\text { Broussonetia papyrifera (L.) L'Hér. ex } \\
\text { Vent. (Moraceae) }\end{array}$ & $\begin{array}{l}\text { Inhibit PL }{ }^{\text {pro }} \text { of SARS-CoV-1 and } \\
\text { MERS-CoV }\end{array}$ & - & Park et al. (2017) \\
\hline Myricetin & Polyphenol & Myristica fragrans Houtt. (Myristicaceae) & $\begin{array}{l}\text { Inhibit helicase and nsP13 of SARS- } \\
\text { CoV-1 }\end{array}$ & - & Yu et al. (2012) \\
\hline Naringin & Flavonoid & Citrus $x$ aurantium L., (Rutaceae) & Inhibit 3CL ${ }^{\text {pro }}$ of SARS-CoV-1 & - & Nguyen et al. (2012) \\
\hline \multirow[t]{2}{*}{ Naringenin } & Flavonoid & Citrus fruits (Rutaceae) & $\begin{array}{l}\text { Two-Pore Channels (TPCs) inhibitor } \\
\text { MERS-CoV }\end{array}$ & - & Pafumi et al. (2017) \\
\hline & & & $\begin{array}{l}\text { Block the enzymatic activity } 3 \mathrm{CL}^{\text {pro }} \text { in } \\
\text { SARS-CoV-1 }\end{array}$ & - & Jo et al. (2020b) \\
\hline Pectolinarin & Flavonoid & $\begin{array}{l}\text { Cirsium chanroenicum (Nakai) Nakai } \\
\text { (Asteraceae) }\end{array}$ & $\begin{array}{l}\text { Block the enzymatic activity of SARS- } \\
\text { CoV-1 } 3 \mathrm{CL}^{\text {pro }}\end{array}$ & - & Jo et al. (2020b) \\
\hline Papyriflavonol A & Flavonoid & $\begin{array}{l}\text { Broussonetia papyrifera (L.) L'Hér. ex } \\
\text { Vent. (Moraceae) }\end{array}$ & $\begin{array}{l}\text { Inhibit PL }{ }^{\text {pro }} \text { of SARS-CoV-1 and } \\
\text { MERS-CoV }\end{array}$ & - & Park et al. (2017) \\
\hline Quercetin & Glycosyloxyflavone & Allium cepa L. (Amaryllidaceae) & Target SARS-CoV2-S spike protein & - & Pan et al., 2020 \\
\hline $\begin{array}{l}\text { Quercetin } 3-\beta-D \\
\text { glucoside }\end{array}$ & Flavonoid & $\begin{array}{l}\text { Passiflora subpeltata Ortega } \\
\text { (Passifloraceae) }\end{array}$ & Inhibit $3 \mathrm{CL}^{\text {pro }}$ of MERS- CoV & - & Jo et al. (2019) \\
\hline Resveratrol & Polyphenol & Vitis vinifera L. (Vitaceae) & $\begin{array}{l}\text { Inhibit nucleocapsid protein } \\
\text { translation in and reduced the MERS- } \\
\text { CoV-mediated apoptosis }\end{array}$ & $\begin{array}{c}\text { Phase } 2 \\
(\text { SARS-CoV- } \\
\text { 2) }\end{array}$ & Lin et al. (2017) \\
\hline Rhoifolin & Flavonoid & $\begin{array}{l}\text { Toxicodendron succedaneum (L.) Kuntze } \\
\text { (syn. Rhus succedanea) (Anacardiaceae) }\end{array}$ & Inhibit 3CL ${ }^{\text {pro }}$ SARS-CoV-1 & - & Nguyen et al. (2012) \\
\hline Rubranoside A & Diarylheptanoids & $\begin{array}{l}\text { Alnus hirsuta (Spach) Rupr. (syn. Alnus } \\
\text { sibirica) (Betulaceae) }\end{array}$ & Inhibit $3 \mathrm{CL}^{\text {pro }}$ and PL ${ }^{\text {pro }} \mathrm{SARS}-\mathrm{CoV}-1$ & - & Park et al. (2016) \\
\hline Rubranoside B & Diarylheptanoids & $\begin{array}{l}\text { Alnus japonica (Thunb.) Steud. } \\
\text { (Betulaceae) }\end{array}$ & Inhibit $3 \mathrm{CL}^{\text {pro }}$ and PL ${ }^{\text {pro }}$ SARS-CoV-1 & - & Park et al. (2016) \\
\hline Scutellarein & Flavonoid & Scutellaria lateriflora L. (Lamiaceae) & Inhibit helicase, nsP13 SARS-CoV-1 & - & Yu et al. (2012) \\
\hline Vanillinbananin & $\begin{array}{l}\text { Oligo-oxa- } \\
\text { adamantane }\end{array}$ & Natural product derivative & $\begin{array}{l}\text { Inhibit NTPase/Helicase of SARS- } \\
\text { CoV-1 }\end{array}$ & - & Tanner et al. (2005) \\
\hline
\end{tabular}

${ }^{a}$ Resveratrol and Zinc Picolinate combination therapy. 
<smiles>O=c1cc(-c2ccccc2)oc2cc(O)c(O)c(O)c12</smiles>

Baicalein<smiles>CC(C)=CCc1cc(C(=O)/C=C/c2ccc(O)cc2)c(O)cc1O</smiles>

Broussochalcone $B$<smiles>O=C(O[C@H]1Cc2c(O)cc(O)cc2O[C@@H]1c1cc(O)c(O)c(O)c1)c1cc(O)c(O)c(O)c1</smiles>

Epigallocatechin gallate<smiles>O=C(O[C@H]1Cc2c(O)cc(O)cc2OC1c1cc(O)c(O)c(O)c1)c1cc(O)c(O)c(O)c1</smiles>

Gallocatechin gallate<smiles>O=c1c(O)c(-c2ccc(Cl)cc2)oc2cc(O)c(O)c(O)c12</smiles><smiles>O=C(CCc1ccc(O)c(O)c1)CC[C@@H](O)CCc1ccc(O)c(O)c1</smiles>

Hirsutanonol<smiles>O=C(/C=C/CCc1ccc(O)c(O)c1)CCc1ccc(O)c(O)c1</smiles><smiles>CC(C)=CCc1c(O)ccc(C(=O)/C=C/c2ccc(O)cc2)c1O</smiles><smiles>O=c1c(OC2OC(CO)[C@@H](O)[C@H](O)[C@H]2O)c(-c2ccc(O)cc2)oc2cc(OC3O[C@H](CO)[C@@H](O)[C@H](O)[C@H]3O)cc(O)c12</smiles>

Kaempferol 3,7-diglucoside<smiles>CC(C)=CCc1c(CCCc2ccc(O)cc2O)cc(O)c(O)c1CC=C(C)C</smiles>

Kazinol F<smiles></smiles><smiles>O=C1CC(c2ccc(O)cc2)Oc2cc(O)cc(O)c21</smiles>

Myricetin

Naringenin<smiles>COc1ccc(-c2cc(=O)c3c(O)c(OC)c(OC4OC(CO[C@H]5OC(C)[C@H](O)[C@H](O)C5O)[C@@H](O)[C@H](O)C4O)cc3o2)cc1</smiles><smiles>CC(C)=CCc1cc(-c2oc3cc(O)c(CC=C(C)C)c(O)c3c(=O)c2O)cc(O)c1O</smiles>

Papyriflavonol A

Quercetin<smiles>O=c1c(O[C@@H]2O[C@H](CO)[C@@H](O)[C@H](O)[C@H]2O)c(-c2ccc(O)c(O)c2)oc2cc(O)cc(O)c12</smiles>

Quercetin 3-B-D-glucoside<smiles>Oc1ccc(/C=C/c2cc(O)cc(O)c2)cc1</smiles>

Resveratrol<smiles>OC[C@H]1O[C@@H](OC(CCCCCc2ccc(O)c(O)c2)CCCc2ccc(O)c(O)c2)[C@H](O)[C@@H](O)[C@@H]1O</smiles>

Rubranoside A<smiles>Oc1ccc(CCCCCC(CCCCc2ccc(O)c(O)c2)O[C@@H]2OC[C@@H](O)C(O)[C@H]2O)cc1O</smiles>

Rubranoside B<smiles>O=c1cc(-c2ccc(O)cc2)oc2cc(O)c(O)c(O)c12</smiles>

Scutellarein

FIGURE 2 | Chemical structures of some natural products introduced in this study.

IL-1 $\beta$, iNOS, and COX-2 induced by LPS treatment. Molecular docking investigation showed that naringin, naringenin, and hesperetin could bind to ACE2, such as chloroquine. Furthermore, these compounds can bind to ACE2 at lower binding energy levels than chloroquine (docking energy of $5.7 \mathrm{kcal} / \mathrm{mol}$ ). However, more in vitro and in vivo experimentation is needed to determine whether these compounds are more effective than chloroquine (da Silva Antonio et al., 2020). However, it should be noted that inhibition of ACE2 due to its important physiological activities (such as homeostasis of blood pressure, protection against pulmonary cell destruction, electrolyte retention, and water) may have detrimental effects on patients' life. In addition to
ACE2, Transmembrane Protein Serine 2 (TMPRSS2) is another essential protein for SARS-CoV-1 and SARS-CoV-2 infection. TMPRSS2 induces viral fusion with the host cell membrane through irreversible structural changes in viral $S$ protein (Hoffmann et al., 2020). As a result, the inhibition of TMPRSS2 in the animal model's airways decreases the severity of lung damage after infection by SARS-CoV and MERS-CoV (Chikhale et al., 2020). Therefore, one of the strategies that could block the entry and restrict the pathogenesis of SARS-CoV-2 is the inhibition of TMPRSS2. The results of two independent studies using computational biology and molecular docking showed that some natural compounds such as neohesperidin, myricitrin, quercitrin, naringin, icariin, citicoline, 


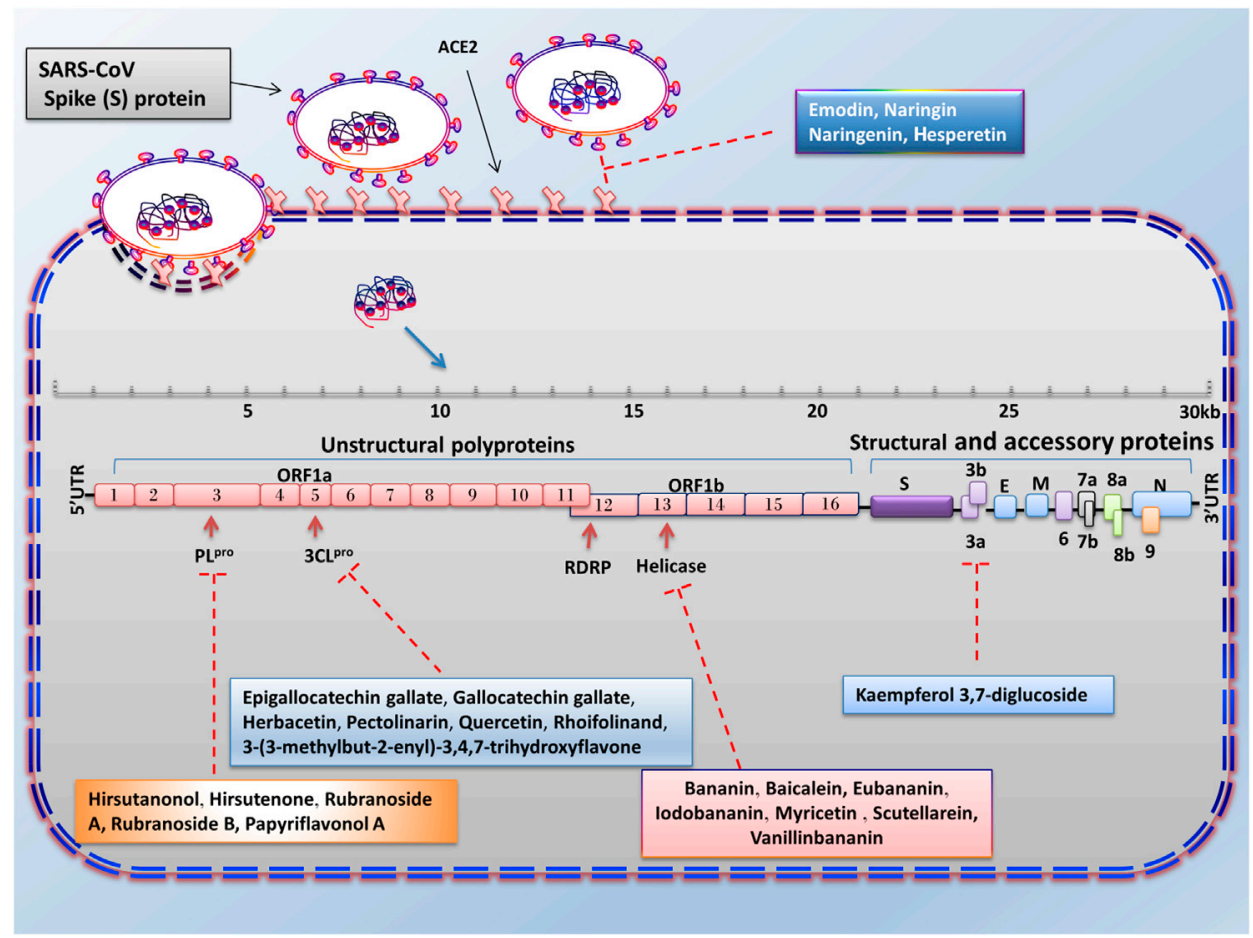

FIGURE 3 | Advantages of employing natural compounds against infection and replication of SARS-CoV. Some of the natural compounds by reducing the expression of $3 \mathrm{CL}^{\text {pro }}, \mathrm{PL}^{\text {pro }}$, helicase, and 3 a genes can play a therapeutic role in inhibiting the SARS-CoV infection.

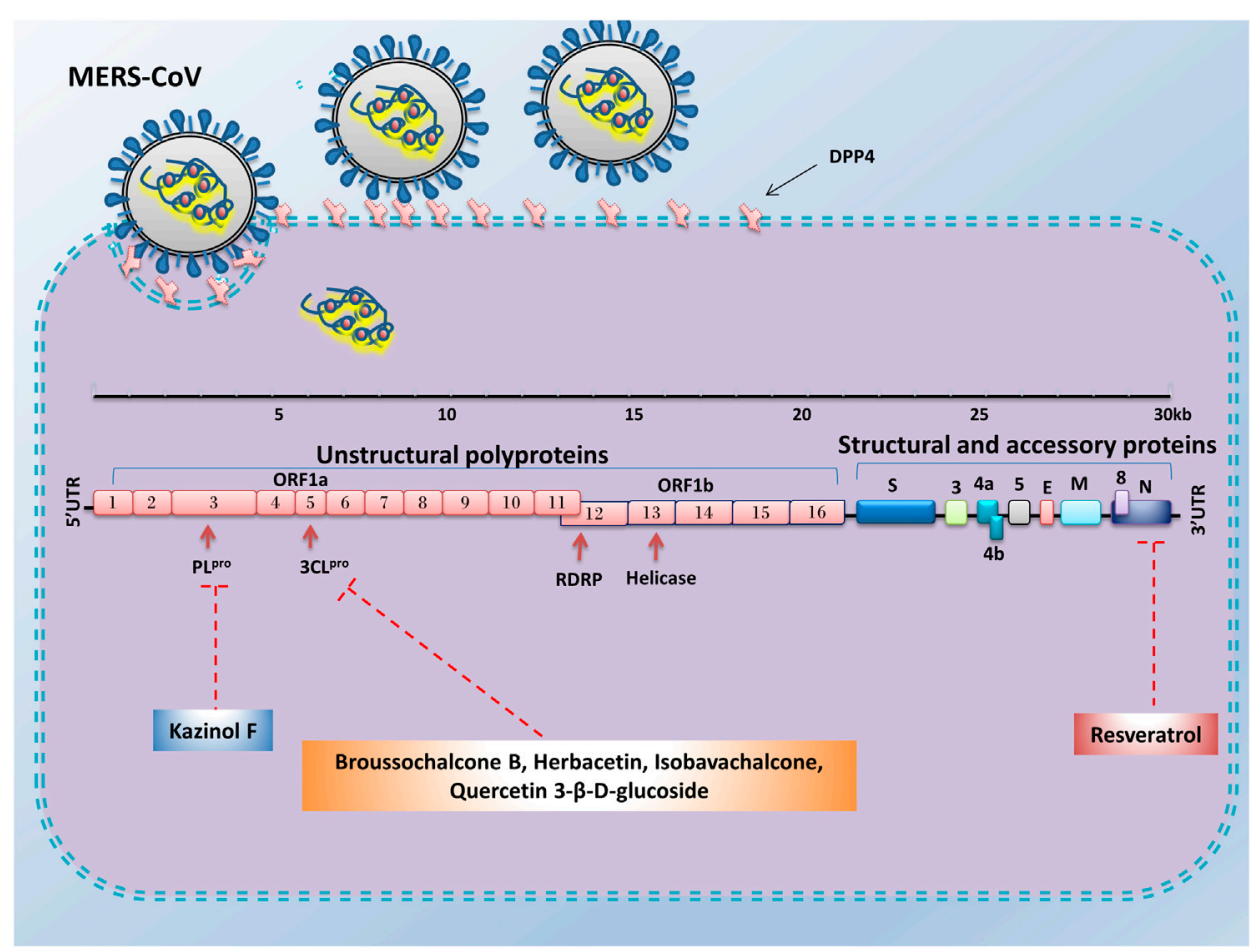

FIGURE 4 | Advantages of employing natural compounds against infection and replication of MERS-CoV. Some of the natural compounds by reducing the expression of nucleocapsid, $3 \mathrm{CL}^{\text {pro }}$, and $\mathrm{PL}^{\text {pro }}$ genes could play a therapeutic role in inhibiting the MERS-CoV infection. 
bianthraquinone, isogemichalcone $\mathrm{B}$, and (-)-epigallocatechin(3-O-methyl) gallate could be used as a TMPRSS inhibitor (Chikhale et al., 2020; Rahman et al., 2020).

\section{Targeting Helicase and Inhibiting Virus Replication}

SARS-CoV-2 Helicase protein is encoded by the nsp 13, a gene located downstream of the RdRP. The inhibition of this protein could reduce virus replication (Ivanov et al., 2004). Helicases could separate the double-stranded Nucleic Acid (NA) by using free energy that is obtained from the hydrolysis of Nucleoside Triphosphate (NTP). Therefore, this protein is a potential target for antiviral drug development. Previous studies revealed that various natural products could suppress helicase (unwinding or ATPase) activity. In 2005, Tanner et al. investigated the effect of adamantane-derived bananins on SARS-CoV helicase.

Their results showed that iodobananin, vanillinbananin, bananin, and eubananin had an inhibitory effect on the helicase protein's ATPase activity with $\mathrm{IC}_{50}$ rates in the range 0.5-2.8 $\mu \mathrm{M}$. Furthermore, using Fluorescence Resonance Energy Transfer (FRET) it was found that these four compounds could also inhibit unwinding helicase activity. The authors also observed that these compounds were ineffective against $E$. coli helicase but only affected SARS helicase, so they did not have a general helicase inhibitor activity. Finally, the results of cytopathic effects in fetal rhesus kidney-4 cells (FRhK-4) and RT-PCR demonstrated that these compounds could reduce virus replication without being toxic to the cell (Tanner et al., 2005). In 2012, the results of a study by Yu et al. showed that of the sixtyfour natural compounds (flavonoids), only myricetin and scutellarein could reduce SARS-CoV helicase activity. The events showed that these two compounds could reduce Helicase ATPase activity by up to $90 \%$ at a dose of $10 \mu \mathrm{M}$ without any toxicity effects on the healthy breast cell (MCF10A). Moreover, further analysis has shown that they do not change the helicase unwinding activity (Yu et al., 2012). Baicalein is another natural product that has an inhibitory effect on SARS-CoV (nsp13) helical activity. Studies have shown that this compound has no inhibitory effect on the dsDNA-unwinding activity of nsP13; however, it can decrease helicase ATPase activity up to $60 \%$ with an $\mathrm{IC}_{50}$ value $0.47 \mu \mathrm{M}$ (Keum et al., 2013).

\section{Targeting $3 \mathrm{CL}^{\mathrm{PRO}}, \mathrm{PL}^{\mathrm{PRO}}$ Protease and Inhibiting Virus Protein Processing}

Another important antiviral strategy is the use of specific inhibitors against viral proteases such as $3 \mathrm{CL}^{\text {pro }}$ and $\mathrm{PL}^{\text {pro }}$, which play an essential role in the processing and maturation of proteins and virus replication. The SARS-CoV-2 genome (positive single-stranded RNA), after translation, is capable of producing two polypeptides, ppla and pplab. Finally, these two polypeptides, cleaved by $3 \mathrm{CL}^{\mathrm{pro}}$ or $\mathrm{PL}^{\text {pro }}$ activity, produce sixteen non-structural proteins (Thiel et al., 2003; Muramatsu et al., 2016). Flavonoids are a group of phenolic compounds found in plants with anti-inflammatory, antiviral, antioxidant, and anticancer activities. There have been many reports of reduced coronavirus infection with these compounds (Tapas et al., 2008). In vitro studies in Pichia pastoris GS115 showed that epigallocatechin-3-gallate, quercetin, and gallocatechin gallate could reduce the expression of SARS-CoV $3 \mathrm{CL}^{\text {pro }}$. Molecular docking experiments and kinetic enzyme studies also revealed that these three compounds with $\mathrm{IC}_{50}$ rates in the range $47-73 \mu \mathrm{M}$ could reduce protease activity up to $80 \%$. In the meantime, gallocatechin gallate's effect was more significant than the other compounds (Nguyen et al., 2012). Rhoifolinand, herbacetin, and pectolinarin are other flavonoid compounds that have an adverse influence on $3 \mathrm{CL}^{\text {pro }}$. Studies with FRET protease assays and absorption spectroscopic studies have shown that these compounds can bind to $3 \mathrm{CL}^{\text {pro }}$ and significantly inhibit its protease activity (drug concentration less than $40 \mu \mathrm{M}$ in $\mathrm{IC}_{50}$ ) (Jo et al., 2020b). In another study, Jo et al. examined the inhibitory effects of several flavonoids compounds against MERS-CoV 3CL ${ }^{\text {pro }}$. Their results reveal the isobavachalcone, quercetin 3- $\beta$-D-glucoside, and herbacetin had noticeable inhibitory actions with $\mathrm{IC}_{50}$ values of $35.85,37.03$, $40.59 \mu \mathrm{M}$, respectively (Jo et al., 2019). The $3 \mathrm{CL}^{\text {pro }}$ of SARS-CoV2 is highly conserved among all CoVs and has approximately $96 \%$ similarity with SARS-CoV-1. Due to its essential role in viral replication, it is a potential therapeutic target for COVID-19 (Xu et al., 2020c). Since natural products derived from microbial sources have a unique chemical diversity compared to plant products, more than $50 \%$ of FDA-approved natural compound-based medicines are derived from microbial compounds. The virtual screening and molecular binding by Sayed et al. showed that citriquinochroman, holyrine B, proximicin $\mathrm{C}$, and several other microbial compounds could inhibit 3CL ${ }^{\text {pro }}$ of SARS-CoV-2 (Sayed et al., 2020). In addition to microbial compounds, molecular docking and MD simulation studies have shown that some marine natural products including hydroxypentafuhalol, pentaphlorethol $\mathrm{B}$, and luteolin-7rutinoside $(\Delta \mathrm{G}$ about -14.6 to $-10.7 \mathrm{kcal} / \mathrm{mol})$ can also inhibit $3 \mathrm{CL}^{\text {pro }}$ of SARS-CoV-2 (Gentile et al., 2020).

The Papain-like protease $\left(\mathrm{PL}^{\mathrm{pro}}\right)$, is another protease that controls the proliferation of SARS-CoV-2 and is known as a potential target for treating this virus. Previous studies have shown that Alnus japonica (Thunb.) Steud. (Betulaceae) has anticancer, anti-inflammatory, and anti-influenza properties. The study of Kim et al. showed that the natural phenolic compounds (diarylheptanoids) prepared from this plant could change the proteolytic activity of $\mathrm{PL}^{\mathrm{pro}}$. The fluorometric assay results showed that among the nine extracted substances, hirsutenone, hirsutanonol, rubranoside $\mathrm{B}$, and rubranoside $\mathrm{A}$ had a dose-dependent inhibitory effect against $\mathrm{PL}^{\mathrm{pro}}$. Among these compounds, hirsutenone had a remarkable inhibitory effect on SARS-CoV PL ${ }^{\text {pro }}\left(\mathrm{IC}_{50}=4.1 \mu \mathrm{M}\right)$ and $3 \mathrm{CL}^{\text {pro }}\left(\mathrm{IC}_{50}=36.2 \mu \mathrm{M}\right)$ enzyme activity. Further study showed that this substance, containing an $\alpha, \beta$-unsaturated carbonyl group with a catechol moiety in the backbone, and the presence of this structure played an essential role in its inhibitory effects (Park et al., 2012a). In addition, polyphenols derived from the root of Broussonetia papyrifera (L.) L'Hér. ex Vent. (Moraceae) have been shown to have good inhibitory potential against SARS-CoV and MERS$\mathrm{CoV}$ proteases. Park et al. investigated the inhibitory effect of ten 
natural compounds derived from this plant on SARS-CoV and MERS-CoV proteases. The effect of these compounds on SARS$\mathrm{CoV}$ proteases showed that the papyriflavonol A (Broussonol E) was the most effective inhibitor of $\mathrm{PL}^{\text {pro }}\left(\mathrm{IC}_{50}\right.$ value $\left.3.7 \mu \mathrm{M}\right)$ and 3-(3-methylbut-2-enyl)-3,4,7-trihydroxyflavone was the most useful inhibitor of $3 \mathrm{CL}^{\text {pro }}\left(\mathrm{IC}_{50}\right.$ value of $\left.30.2 \mu \mathrm{M}\right)$. Additionally, broussochalcone $\mathrm{B}$ (Bavachalcone), with a concentration of $27.9 \mu \mathrm{M}\left(\mathrm{IC}_{50}\right)$ and kazinol $\mathrm{F}$ with a concentration of $39.5 \mu \mathrm{M}\left(\mathrm{IC}_{50}\right)$, were able to reduce the activity of MERS-CoV 3CL ${ }^{\text {pro }}$ and MERS-CoV PL ${ }^{\text {pro }}$, respectively (Park et al., 2017).

\section{Targeting Nucleocapsid (N) Protein to Inhibit Virus Infection and Replication}

Resveratrol is a natural compound with anti-inflammatory, antioxidant, and anticancer properties (Yeung et al., 2019; Filardo et al., 2020). The previous study demonstrated that this compound has antiviral activity and can inhibit viral infections caused by Herpes Simplex Virus (HSV), Respiratory Syncytial Virus (RSV), and Epstein-Barr Virus (EBV) (Faith et al., 2006; Zang et al., 2011; De Leo et al., 2012). Also, resveratrol by repressing the expression of MERS-CoV N protein in the Vero E6 cell line, could reduce RNA expression, viral yield, and replication of MERS-CoV. Additionally, it significantly decreases the virus's infection and enhances infected cells' survival by repressing Caspase 3 cleavage (Lin et al., 2017). Other natural compounds that can reduce coronavirus infection risk include the alkaloids fangchinoline, cepharanthine, and tetrandrine. The results of a study by Kim et al. showed that these compounds could inhibit the expression of pro-inflammatory cytokines (IFN- $\alpha 1$, IL-6, IFN- $\beta 1$, IL-8, and IL-1) caused by human coronavirus OC43 infection in the MRC- 5 cell line. These three natural compounds can also decrease the OC43 replication by inhibiting $\mathrm{N}$ protein expression and reducing the cytotoxic effect of this virus in the MRC-5 cell line, and increasing the proliferation and survival of MRC-5 human lung cells (Kim et al., 2019).

\section{Targeting 3A Protein and Inhibiting Virus Release}

The production and release of the virus require some ion channels in the host cell membrane. Therefore, inhibition of these ion channels played a significant role in inhibiting viral infections, so one antiviral strategy is to use compounds that can restrain these channels (Liang and Li, 2010). One of these ion channels is the cation-selective channel (3a protein) generated by the ORF3a of the SARS-CoV genome. Kaempferol glycoside is a natural flavonol found in a variety of plants. Previous studies have shown that this compound has antiviral properties ( $\mathrm{IC}_{50}$ value of $2.3 \mu \mathrm{M}$ ) and can inhibit the expression of 3a protein SARS CoV (an ion channel) in Xenopus oocyte as a model system (Schwarz et al., 2014).

\section{RNA INTERFERENCE}

RNA interference (RNAi) are RNA molecules found in many eukaryotes that inhibit gene expression by targeted 3UTR of
mRNA molecules. Today, siRNA and miRNA are the most common type of RNAi used for gene silencing. RNAi origin can be endogenous (originating in the cell) and exogenous (coming from a virus or laboratory tools). Exogenous RNAi can be transmitted to cells using electroporation, viral vectors, liposomes, and calcium phosphate (Sohrab et al., 2018). When inserting into the cell, synthetic siRNAs are cleaved by Dicer in the cytoplasm. After placement in the RNA-Induced Silencing Complex (RISC) and Ago2, RNAi molecules (Figure 5) become single-stranded RNA and can destroy the target mRNA or inhibit its translation (Ding et al., 2018).

\section{The Therapeutic Effect of siRNA on Coronaviruses}

Synthetic siRNAs have about 21-23 bp length and perform their role by inhibiting gene expression at the post-transcription level. Unlike miRNAs, each siRNA is designed against a specific gene, so it can only impede that gene expression (Taxman et al., 2006). The siRNAs are first inserted into the cell as long double-stranded RNAs and then are cleaved by RNase III (Dicer) in the cytoplasm to become small dsRNAs of approximately twenty-one base pairs. This dsRNA later enters the RISC and converts to single-stranded RNA (ssRNA). If RISC and siRNAs complex could find the specific target site on mRNA, it could cleave the mRNA, and cellular exonucleases could invade to destroy the target mRNA (Wu and Chan, 2006). Studies have shown that this type of RNAi has the potential to act as antiviral agent to reduce replication and infection of many viruses such as HIV, Flock House Virus (FHV), Hepatitis C Virus (HCV), and Hepatitis B Virus (HBV) (Hamasaki et al., 2003; Liu et al., 2017; Shahid et al., 2017; Taning et al., 2018). Previous studies have shown that siRNA could target different parts of the virus genome to reduce the replication and infection of SARS-CoV (Figure 6A). For example, targeting the nsp1 gene (from nucleotides 250-786) by siRNA is one of the best ways to control SARS-CoV. Because targeting this area of the genome inhibits virus propagation, pathogenesis, and replication in Vero E6 cells (Ni et al., 2005). Another strategy that can help to suppress infection and replication of SARS-CoV is inhibiting the virus $S$ protein or its specific receptor ACE2.

The SARS-CoV Spike protein is an essential viral surface glycoprotein for identifying target cells and interacting with ACE2 host cell receptors (Gallagher and Buchmeier, 2001). A study by Zhang et al. reveals that inhibiting expression of $\mathrm{S}$ protein using specific siRNAs could reduce the viral titers, infection, and replication of SARS-CoV in Vero E6 and $293 \mathrm{~T}$ cells (Zhang et al., 2004). RNAi technology is also a useful instrument to suppress ACE2 expression at the host cells' surface to counteract SARS-CoV infection. In addition to the lungs, ACE2 is expressed on the surface of the bronchial, renal, duodenum, colon, gastrointestinal, and cardiovascular cells (Donoghue et al., 2000). Inhibition of the ACE2 protein in Vero E6 cell lines using siRNA could reduce replication, copies number, and infection of severe acute respiratory syndromeassociated coronavirus ( $\mathrm{Lu}$ et al., 2008). Li et al. investigated the effect of siSC5 (nsp12 region) and siSC2 (spike protein) against SARS-CoV on in vitro and in vivo models. Their results showed 


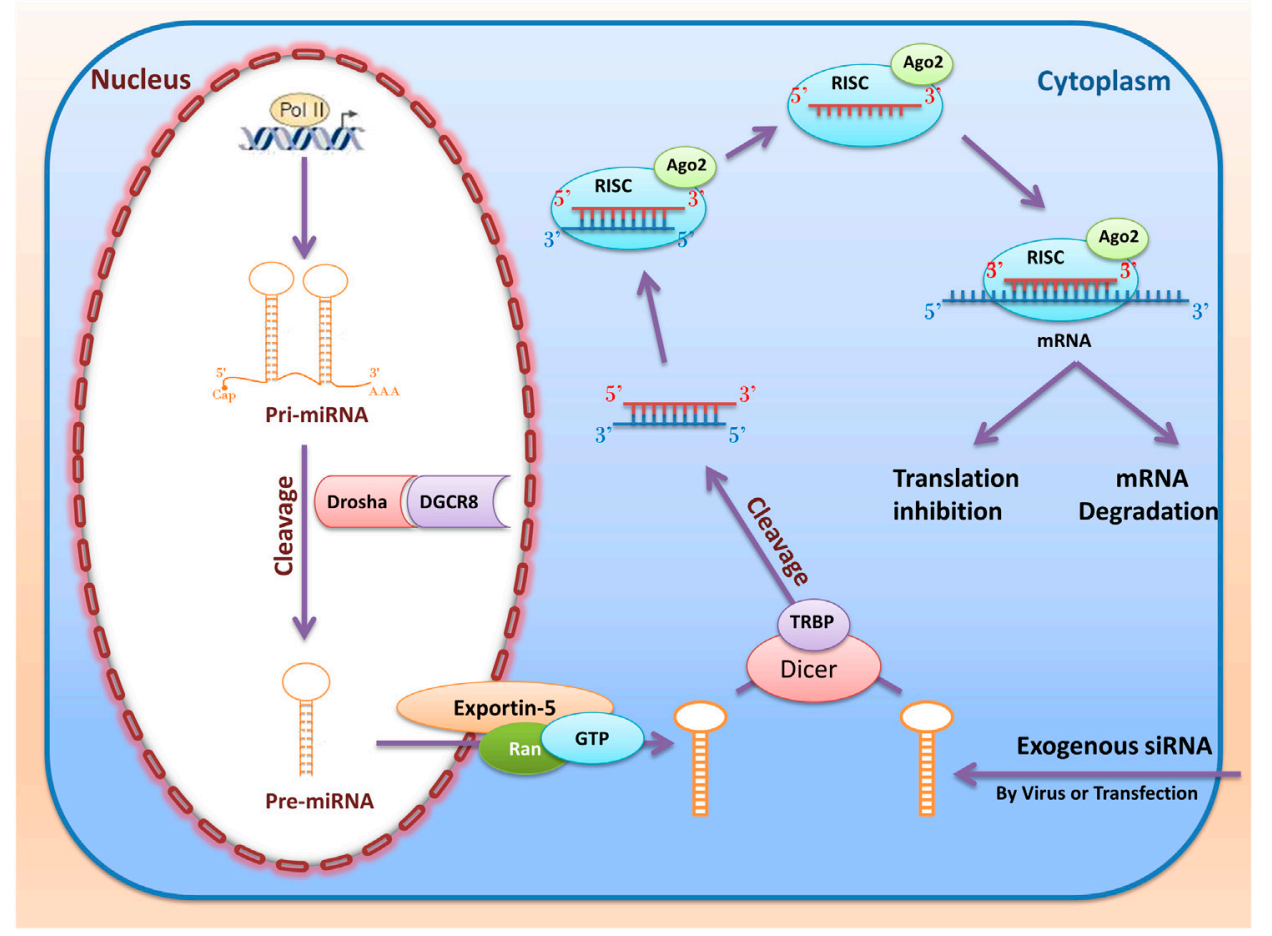

FIGURE 5 | RNA interference (miRNAs and siRNAs) biogenesis and function. The miRNAs first transcribed from the nucleus genome as pri-miRNA. Then primiRNA cleavage with Drosha and DGCR and converted to pre-miRNA. Then, RanGTP and exportin 5 cause the pre miRNA to be transported from the nucleus to the cytoplasm and cleavage by Dicer and TRBP. Ultimately, after entering the RISC complex, mature miRNA can be attached to the target mRNA and perform their function by destroying mRNA or inhibiting the translation. When inserting into the cell, synthetic siRNAs are cleaved by Dicer in the cytoplasm. This dsRNA enters RISC, and if cold finds the target mRNA, the mRNA is cleaved by the RISC and Ago2.

that these two siRNAs by inhibited virus replication in FRHK-4 cells could reduce the virus infection's effects and symptoms without having any toxicity effect on Rhesus macaque (dosages of 10-40 mg/kg) (Li et al., 2005a).

The spike protein structure determines the type of host cells which could be infected by a virus. However, variations of $S$ protein are seen among the various strains of coronavirus. Therefore, one of the essential strategies for controlling viral infections targets the conserved genome areas between various coronaviruses (Kuo et al., 2000). Hence, Wang et al. tried to use two specific siRNAs against the conserved sequence of the SARS$\mathrm{CoV}$. The study results showed that by targeting two regions (14,450-14,468 and 15,877-15,895), encoding RNA polymerase could inhibit expression of RNA polymerase, $\mathrm{N}$ protein, $3 \mathrm{CL}^{\text {pro }}$ and also reduce replication and cytopathic effect of the virus (Wang et al., 2004). Among the two COVID-19 proteases, the nsp3 sequence encoding papain-like protease is less conserved, while the nsp5 sequence encoding $3 \mathrm{CL}^{\text {pro }}$ is highly conserved and can be selected as a potential target of siRNA for COVID-19 treatment (Liu et al., 2020).

The RdRP gene encodes a key enzyme for the replication of the virus. In SARS-CoV-2, this gene is located in ORF1b by $645 \mathrm{bp}$ long and has been reported to be highly conserved, so it has the potential to target several siRNAs. Also, investigations of the RdRP sequence have shown that this gene has no genetic similarity to human genes and other coronaviruses (Wu et al.,
2020). Lu et al.'s investigation shows using specific siRNA can reduce SARS-CoV RdRP expression by more than $90 \%$ in HeLa and $239 \mathrm{~T}$ cell lines, leading to inhibition of plaque formation in Vero E6 cells. Therefore, its suppression could be considered a suitable therapeutic target in COVID-19 patients (Lu et al., 2004). The siRNAs could target other essential coronavirus genes. For example, by designing three different siRNAs, Shi et al. were able to reduce the expression of $\mathrm{N}, \mathrm{E}$, and $\mathrm{M}$ genes of SARS-CoV in Vero E6 cells (Yi et al., 2005). Furthermore, the replication of SARS-CoV could be inhibited by targeting the leader sequence using specific siRNA in Vero E6 cells (Li et al., 2005b).

Although previous studies have shown that RNAi has antiviral potential, it appears that viruses can use these molecules to their advantage. MERS-CoV could infect both human and bat cell lines. Nevertheless, its pathogenic power and replication are varied between the bat (Eptesicus fuscus) cells and human (A549, MRC5, and Huh7) cell lines. In human cells, MERS$\mathrm{CoV}$ shut-down interferon antiviral responses in the innate immunity system, unlike in bat cells by inhibition of IRF3 (a critical activator for INF $\beta$ expression) (Banerjee et al., 2019).

Complemented palindromic small RNAs (cpsRNAs) are a group of small RNAs produced by mammalian and invertebrate viruses. There are sequences in the SARS-CoV (ORF3b) genome that have the origin of a cpsRNA called SARS-CoV-cpsR-19. The apoptosis assay events indicate that SARS-CoV-cpsR-19 could induce apoptosis in HeLa cells by 


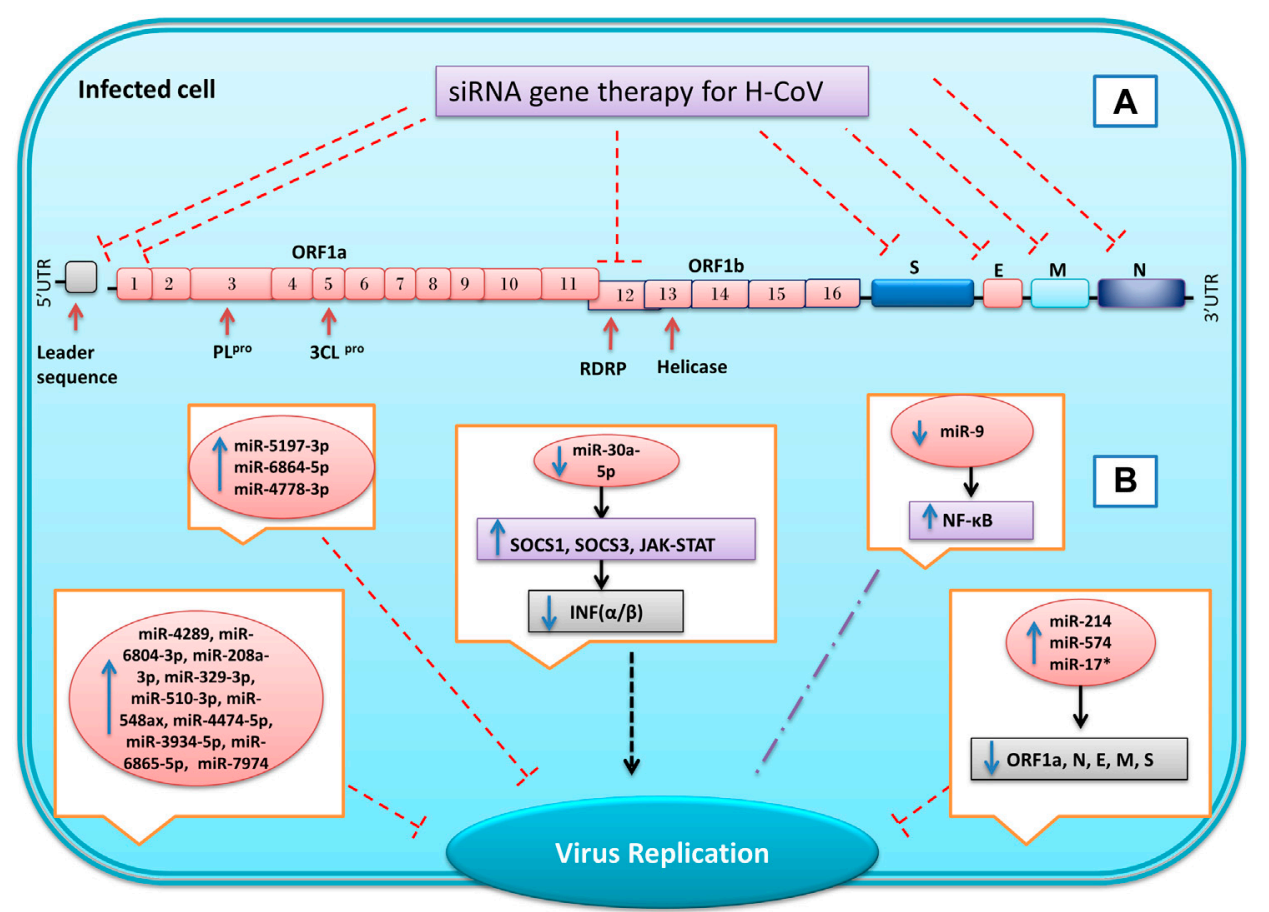

FIGURE 6 | Inhibition of genes expression of SARS coronavirus using miRNAs and synthetic small interfering RNAs (siRNA). By designing specific siRNAs, it is possible to inhibit the expression of the virus's structural and non-structural genes for reduce the replication and infusion of the virus (A). In coronavirus infection, the microRNAs expression of host cells changes in response to infection. Some of these changes are the cell's response to the infection, and others are caused by the virus, which can eventually lead to a reduction or increase in virus replication and infection (B) Inhibition ${ }_{1}^{\top}$, Induction $\downarrow$, not define , Up-regulation $\uparrow$, Down-regulation $\downarrow$.

increasing the caspase 3 and BAX/BCL2 ratio and may play an essential role in SARS-CoV pathogenesis (Liu et al., 2018). It has been shown that some viruses (such as the Ebola virus and influenza A) could preserve themselves from RNAi-based immune systems and facilitate their replication by using Viral Suppressors of RNA silencing (VSR). Studies of Cui et al. have shown a short hairpin RNA (a novel VSR) in the SARS-CoV nucleocapsid protein sequence that defeats RNAi-triggered suppression (Cui et al., 2015). Moreover, N protein overexpression in Neuro-2a cells efficiently inhibits Dicermediated dsRNA cleavage and could increase replication and titration of MHV-A59 (a close relative to SARS-CoV in Coronaviridae family) viruses. The SARS-CoV-2 (N) nucleocapsid protein can also act as an escape agent from the immune system and contribute to its pathogenicity. $\mathrm{N}$ proteins have high homology (94\%) of the amino acid sequences among coronaviruses. A recent study has shown that the $\mathrm{N}$ protein of SARS-CoV-2 has VSR activity that can antagonize RNAi in both effectors (recognition and cleavage of viral dsRNA by Dicer) and initiation (siRNA biogenesis) steps (Mu et al., 2020).

\section{MicroRNAs}

The miRNAs are a group of small non-coding RNAs with twentytwo nucleotides of length. These molecules are first transcribed from the nucleus genome (exons, introns, and intergenic regions) as pri-miRNA with a length of two hundred nucleotides to several thousand nucleotides (Booton and Lindsay, 2014). It is noteworthy that each pri-miRNA can be a precursor to several mature miRNAs. Then, first processing of pri-miRNA starts with RNase III (Drosha) and its cofactor (DGCR) to form pre-miRNA, a hairpin with a length of about sixty nucleotides. In the next step, RanGTP and exportin 5 cause the pre-miRNA to be transported from the nucleus to the cytoplasm. Dicer and TRBP performed the second processing in the cytoplasm to create a doublestranded RNA molecule with a length of about twenty-two nucleotides (Bartel, 2004). Ultimately, after entering the RISC complex, one of the strings (passenger strand) is destroyed, and mature miRNA (guide strand) can be attached to the target mRNA. MiRNAs perform their function by destroying mRNA or inhibiting the translation (Vazquez, 2006). Previous studies have shown that a miRNA alone can regulate the expression of several different genes by its function. Meanwhile, various miRNAs can simultaneously control the expression of one mRNA. However, about $60 \%$ of human genes can be regulated by these molecules (Kalhori et al., 2020). For the first time, Lecellier et al. (2005) reported that cellular miR-32 could reduce virus replication of the primate foamy virus (PFV-1) by targeting the viral RNA genome (Lecellier et al., 2005).

\section{MicroRNA Regulates the Innate Immune System, Virus Replication, and Pathogenesis of Coronavirus}

The innate immune system is the body's first defense against viruses and bacteria. This system's principal cells include macrophages, dendritic cells, natural killer cells, monocytes, and granulocytes 
(Leon-Icaza et al., 2019). Viruses, to increase replication, suppress the host's innate immune system via reducing INF $\alpha / \beta$ production. For example, Japanese Encephalitis Virus (JEV), Dengue Virus (DENV), and Enterovirus 71 (EV71) are able to inhibit the overexpression of INF $\alpha / \beta$ in response to viral infection by enhancing the expression of miR-146a in infected cells (Wu et al., 2013; Ho et al., 2014; Sharma et al., 2015). Viruses can also decrease the innate immune system by inhibiting the expression or function of some miRNAs. For instance, in oligodendroglioma cells, the Borna Disease Virus (BDV) can inhibit the expression of miR155 by its specific phosphoprotein, thus inhibiting INF $\alpha / \beta$ overexpression in response to viral infection and reducing the innate immune system (Zhai et al., 2013). Therefore, one of the main antiviral components of the intrinsic immune system is type 1 interferons (INF $\alpha / \beta$ ).

Coronaviruses can prevent the induction of the immune system in response to viral infection with different strategies. In vivo and in vitro studies of $\mathrm{Ma}$ et al. on the Transmissible Gastroenteritis Virus (TGEV), a member of the alphacoronavirus family, showed that this virus could downregulate miR-30a-5p expression. Furthermore, they found that virus replication was facilitated by reducing IFN-I signaling cascades via removing the inhibitory effect of miR-30a-5p on INF negative regulators (such as SOCS1, SOCS3, and JAK-STAT) (Ma et al., 2018). Therefore, the overexpression of miRNAs in infected cells could increase the innate immune system and may be considered as a therapeutic approach for treatment.

Although it has previously been reported that miRNAs play a significant role in regulating the eukaryotic gene, subsequent studies showed that these nano molecules can also alter the virus's replication to increase or decrease its infection (Figure 6B). For example, miR-122 plays an essential role in the pathogenesis and replication of the Hepatitis $C$ virus. The miR-122, to increase the virus's stability and replication bind to the $5^{\prime}$ non-translated regions (NTRs) of the virus and repress RNA degradation via exonucleases. Therefore, the knockout of this miRNA in Huh-7 cells could reduce HCV replication (Jopling et al., 2005). In contrast, miR-32 could negatively alter the replication of the PFV-1 by targeting viral genes in the human HEK-293T cell line (Lecellier et al., 2005).

Some viruses have sequences (hairpin) in their genomes similar to miRNAs and can regulate the gene expression of the host cell or virus (Grundhoff and Sullivan, 2011; Kincaid and Sullivan, 2012). A computational approach study by Hassan et al. showed there are several hairpins in the genome of the MERS that could act as a precursor for thirteen miRNAs, which were significantly similar to human miRNAs. Their study showed ten miRNAs (miR-4289, miR-6804-3p, miR-208a-3p, miR-3293p, miR-510-3p, miR-548ax, miR-4474-5p, miR-3934-5p, miR6865-5p, and miR-7974) of these, miRNAs do not have any known specific biological function in humans or animals at all. Nevertheless, miR-18a, miR-628, and miR-342-3p had a biological role in humans related to Basal Cell Carcinoma (BCC) of the skin, malignant glioblastoma, and late-stage prion disease, respectively (Hasan et al., 2014). Numerous studies and reports suggest that some miRNAs have antiviral activity and can be used against influenza, HIV, HBV, and poliovirus (PV) (Sanghvi and Steel, 2012; Zhang et al., 2013; Shim et al., 2016; Hamada-Tsutsumi et al., 2019). On the other hand, viruses could alter the gene and miRNA expression profile in the host cell. For example, miR-146a and miR-130b upregulated by the human T Cell Leukemia Virus (HTLV-1) in PBMC cells (Bouzar and Willems, 2008).

Nucleocapsid $(\mathrm{N})$ protein is a structural protein that has the same function in all coronaviruses. The human coronavirus $\mathrm{CoV}$ OC43 could inhibit miR-9 function by its $\mathrm{N}$ protein and increase NF- $\kappa \mathrm{B}$ expression in 253T cells. However, it is unclear whether upregulation NF- $\kappa \mathrm{B}$ is a suitable response for virus replication or a secondary inhibitor for virus replication (Lai et al., 2014). Infection of bronchoalveolar stem cells (BASICs) by SARS$\mathrm{CoV}$ reveals that this virus could upregulate the expression of miR-574-5p, miR-214, and miRNAs-17* 2-4 fold. Moreover, overexpression of these miRNAs could repress SARS-CoV replication by targeting the four viral structure proteins $(\mathrm{E}, \mathrm{S}$, M, N), and orfla (Mallick et al., 2009). Unfortunately, to date, not many in vivo and in vitro studies have been performed on RNAi's role in inhibiting the COVID-19, and most studies have been performed base on bioinformatics and in silico studies. Qingfei Paidu decoction (QFPD) contains twenty-one traditional Chinese medicines that have been used to treat COVID-19 since February 7, 2020. Chen et al.'s molecular docking study revealed that QFPD can bind to structural and non-structural proteins of COVID-19. They also found that miR-183 and miR-130A/B/301 predict targets of QFPD, and QFPD by these microRNAs may exert anti-SARS-CoV-2 activity (Chen et al., 2020a). In a bioinformatics approach study performed by Khan et al., it was found that several miRNAs can have antiviral properties in infections caused by SARS-CoV-1 and SARS-CoV-2. For example, evidence has shown miR-323a-5p, miR-622, miR198, and miR-654-5p for SARS-CoV-1 and miR-323a-5p, miR-20b-5p, miR-17-5p for SARS-CoV-2 have antiviral roles by targeting the ORF1ab and the S region (Khan et al., 2020).

Therefore, it is likely miRNA with low side effects can be used as a therapeutic agent for the COVID-19 treatment. Differences in miRNA expression profiles in individuals are probably one reason why COVID-19 causes death in some people and causes only brief symptoms in others. As a result, microRNAs have recently emerged as a critical factor in increasing or inhibiting the potential of viral infection. We hope that clinical and preclinical research can use them in gene therapy as antiviral agents soon.

\section{CONCLUSION}

Today, the whole world is suffering from a pandemic disease called COVID-19, which has caused deaths in many developed and developing countries. Despite all the advances in human medicine, we have not yet been able to find a suitable treatment for this viral disease. The use of molecular or pharmacological methods to control infection or virus replication requires identifying essential genes involved in infection and replication of the virus. Two strategies are suggested to treat this disease. The first step is to reduce the virus's infection by preventing the virus from attaching to its specific receptor. The next step is to reduce the 
virus's replication by inhibiting the virus's structural and nonstructural genes. Medicinal plants and natural products are a good option for preventing and treating viral infections, especially COVID-19, due to their lower cost, lower side effects, and natural origin compared with chemical drugs. These compounds could increase efficiency and strengthen the host immune system against many infections and diseases due to their inherent properties. In the treatment of COVID-19, these compounds can reduce virus infection or replication by repressing the virus's coupling to the host cell's receptors or by inhibiting the expression of structural and non-structural genes. Moreover, RNAi (siRNA and miRNA) could inhibit viral infections, especially COVID-19, by inhibiting essential virus genes or inducing a host immune system. Therefore, the simultaneous use of natural compounds and RNAi can play a critical role in the treatment of SARS-CoV-2 and restraining this pandemic pneumonia.

\section{REFERENCES}

Ahn, D.-G., Choi, J.-K., Taylor, D. R., and Oh, J.-W. (2012). Biochemical characterization of a recombinant SARS coronavirus nsp12 RNAdependent RNA polymerase capable of copying viral RNA templates. Arch. Virol. 57, 2095-2104. doi:10.1007/s00705-012-6751404-x10.1007/ s00705-012-1404-x

An, S., Chen, C.-J., Yu, X., Leibowitz, J. L., and Makino, S. (1999). Induction of apoptosis in murine coronavirus-infected cultured cells and demonstration of $\mathrm{E}$ protein as an apoptosis inducer. J. Virol. 73, 7853-7859. doi:10.1128/JVI.73.9. 7853-7859.1999

Angelini, M. M., Akhlaghpour, M., Neuman, B. W., and Buchmeier, M. J. (2013). Severe acute respiratory syndrome coronavirus nonstructural proteins 3,4 , and 6 induce double-membrane vesicles. MBio. 4, e00524-e00513. doi:10.1128/ mBio.00524-13

Angelini, M. M., Neuman, B. W., and Buchmeier, M. J. (2014). Untangling membrane rearrangement in the nidovirales. DNA Cell Biol. 33, 122-127. doi:10.1089/dna.2013.2304

Banerjee, A., Falzarano, D., Rapin, N., Lew, J., and Misra, V. (2019). Interferon regulatory factor 3-mediated signaling limits Middle-East respiratory syndrome (MERS) coronavirus propagation in cells from an insectivorous bat. Viruses 11, 152. doi:10.3390/v11020152

Bartel, D. P. (2004). MicroRNAs: genomics, biogenesis, mechanism, and function. Cell 116, 281-297. doi:10.1016/s0092-8674(04)00045-5

Booton, R., and Lindsay, M. A. (2014). Emerging role of MicroRNAs and long noncoding RNAs in respiratory disease. Chest 146, 193-204. doi:10.1378/chest. 13-2736

Bosch, B. J., Van Der Zee, R., De Haan, C. A., and Rottier, P. J. (2003). The coronavirus spike protein is a class I virus fusion protein: structural and functional characterization of the fusion core complex. J. Virol. 77, 8801-8811. doi:10.1128/jvi.77.16.8801-8811.2003

Bouvet, M., Debarnot, C., Imbert, I., Selisko, B., Snijder, E. J., Canard, B., et al. (2010). In vitro reconstitution of SARS-coronavirus mRNA cap methylation. PLoS Pathog. 6 (4), e1000863. doi:10.1371/journal.ppat. 1000863

Bouvet, M., Imbert, I., Subissi, L., Gluais, L., Canard, B., and Decroly, E. (2012). RNA 3 '-end mismatch excision by the severe acute respiratory syndrome coronavirus nonstructural protein nsp10/nsp14 exoribonuclease complex. Proc. Natl. Acad. Sci USA 109, 9372-9377. doi:10.1073/pnas.1201130109

Bouzar, A. B., and Willems, L. (2008). How HTLV-1 may subvert miRNAs for persistence and transformation. Retrovirology 5, 101. doi:10.1186/1742-4690$5-101$

Cai, Q., Yang, M., Liu, D., Chen, J., Shu, D., Xia, J., et al. (2020). Experimental treatment with Favipiravir for COVID-19: an open-label control study. Engineering 6 (10), 1192-1198. doi:10.1016/j.eng.2020.03.007

\section{AUTHOR CONTRIBUTIONS}

The study was conceptualized by MS and EA. The methodology was given by EA and MF. Writing and original draft preparation was done by MK and FS. Writing, review, and editing were done by MF, IA, and JE. Funding acquisition was provided by MK and JE. All authors contributed to the article and approved the submitted version.

\section{FUNDING}

This work was supported by the Kermanshah University of Medical Sciences (grant numbers 990512). JE gratefully acknowledges funding from CONICYT (PAI/ACADEMIA No 79160109).

Casals, J., Tignor, G. H., Lack, E. E., Jenson, B., Smith, H. G., Healy, G. B., et al. (1980). International committee for Taxonomy of viruses. Intervirology 14, 228. doi: $10.1159 / 000149188$

Cascella, M., Rajnik, M., Cuomo, A., Dulebohn, S. C., and Di Napoli, R. (2020). "Features, evaluation and treatment coronavirus (COVID-19)," in Statpearls (Treasure Island, FL: StatPearls Publishing).

Cavanagh, D. (1995). "The coronavirus surface glycoprotein," in The coronaviridae. Boston, MA: Springer, 73-113. doi:10.1007/978-1-48991531-3_5

Cawood, R., Harrison, S. M., Dove, B. K., Reed, M. L., and Hiscox, J. A. (2007). Cell cycle dependent nucleolar localization of the coronavirus nucleocapsid protein. Cell Cycle 6, 863-867. doi:10.4161/cc.6.7.4032

Centers for Disease Control and Prevention (2012). Severe respiratory illness associated with a novel coronavirus--Saudi Arabia and Qatar, 2012. MMWR Morb. Mortal. Wkly. Rep. 61 (40), 820.

Chen, J., Wang, Y. K., Gao, Y., Hu, L. S., Yang, J. W., Wang, J. R., et al. (2020a). Protection against COVID-19 injury by qingfei paidu decoction via anti-viral, anti-inflammatory activity and metabolic programming. Biomed. Pharmacother. 129, 110281. doi:10.1016/j.biopha.2020.110281

Chen, Z. M., Fu, J. F., Shu, Q., Chen, Y. H., Hua, C. Z., Li, F. B., et al. (2020b). Diagnosis and treatment recommendations for pediatric respiratory infection caused by the 2019 novel coronavirus. World J. Pediatr. 16, 240-246. doi:10. 1007/s12519-020-00345-5

Chikhale, R. V., Gupta, V. K., Eldesoky, G. E., Wabaidur, S. M., Patil, S. A., and Islam, M. A. (2020). Identification of potential anti-TMPRSS2 natural products through homology modelling, virtual screening and molecular dynamics simulation studies. J. Biomol. Struct. Dyn. 1-16, 1-16. doi:10.1080/07391102. 2020.1798813

Chu, C., Cheng, V., Hung, I., Wong, M., Chan, K., Chan, K., et al. (2004). Role of lopinavir/ritonavir in the treatment of SARS: initial virological and clinical findings. Thorax 59, 252-256. doi:10.1136/thorax.2003.012658

Colson, P., Rolain, J.-M., and Raoult, D. (2020). Chloroquine for the 2019 novel coronavirus SARS-CoV-2. Int. J. Antimicrob. Agents 55 (3), 105923. doi:10. 1016/j.ijantimicag.2020.105923

Cornillez-Ty, C. T., Liao, L., Yates, J. R., Kuhn, P., and Buchmeier, M. J. (2009). Severe acute respiratory syndrome coronavirus nonstructural protein 2 interacts with a host protein complex involved in mitochondrial biogenesis and intracellular signaling. J. Virol. 83, 10314-10318. doi:10.1128/JVI.00842-09

COVID-19 Treatment Guidelines Panel (2019). Coronavirus disease 2019 (COVID-19) treatment guidelines. Bethesda, MD: National Institutes of Health. Available at: https://www.covid19treatmentguidelines.nih.gov/

Cui, L., Wang, H., Ji, Y., Yang, J., Xu, S., Huang, X., et al. (2015). The nucleocapsid protein of coronaviruses acts as a viral suppressor of RNA silencing in mammalian cells. J. virol. 89, 9029-9043. doi:10.1128/jvi.01331-15

Danesh, A., Cameron, C. M., León, A. J., Ran, L., Xu, L., Fang, Y., et al. (2011). Early gene expression events in ferrets in response to SARS coronavirus infection 
versus direct interferon-alpha2b stimulation. Virology 409, 102-112. doi:10. 1016/j.virol.2010.10.002

da Silva Antonio, A., Wiedemann, L. S. M., and Veiga-Junior, V. F. (2020). Natural products' role against COVID-19. RSC Adv. 10, 23379-23393. doi:10.1039/ D0RA03774E

De Lang, A., Osterhaus, A. D., and Haagmans, B. L. (2006). Interferon-gamma and interleukin-4 downregulate expression of the SARS coronavirus receptor ACE2 in Vero E6 cells. Virology 353, 474-481. doi:10.1016/j.virol.2006.06.011

De Leo, A., Arena, G., Lacanna, E., Oliviero, G., Colavita, F., and Mattia, E. (2012). Resveratrol inhibits Epstein Barr Virus lytic cycle in Burkitt's lymphoma cells by affecting multiple molecular targets. Antiviral Res. 96, 196-202. doi:10.1016/ j.antiviral.2012.09.003

Deng, L., Li, C., Zeng, Q., Liu, X., Li, X., Zhang, H., et al. (2020). Arbidol combined with $\mathrm{LPV} / \mathrm{r}$ versus $\mathrm{LPV} / \mathrm{r}$ alone against corona virus disease 2019: a retrospective cohort study. J. Infect. 81 (1), e1-e5. doi:10.1016/j.jinf.2020.03.002

Denison, M. R., Graham, R. L., Donaldson, E. F., Eckerle, L. D., and Baric, R. S. (2011). Coronaviruses: an RNA proofreading machine regulates replication fidelity and diversity. RNA Biol. 8, 270-279. doi:10.4161/rna.8.2.15013

Dias, D. A., Urban, S., and Roessner, U. (2012). A historical overview of natural products in drug discovery. Metabolites 2, 303-336. doi:10.3390/ metabo2020303

Ding, S. W., Han, Q., Wang, J., and Li, W. X. (2018). Antiviral RNA interference in mammals. Curr Opin Immunol 54, 109-114. doi:10.1016/j.coi.2018.06.010

Ding, Y., Wang, H., Shen, H., Li, Z., Geng, J., Han, H., et al. (2003). The clinical pathology of severe acute respiratory syndrome (SARS): a report from China. J. Pathol. 200, 282-289. doi:10.1002/path.1440

Donoghue, M., Hsieh, F., Baronas, E., Godbout, K., Gosselin, M., Stagliano, N., et al. (2000). A novel angiotensin-converting enzyme-related carboxypeptidase (ACE2) converts angiotensin I to angiotensin 1-9. Circ Res 87, e1-e9. doi:10.1161/01.res.87.5.e1

Enjuanes, L., Brian, D., Cavanagh, D., Holmes, K., Lai, M., Laude, H., et al. (2000). Coronaviridae. Virus Taxonomy, Classification and Nomenclature of viruses. Editors M. A. Murphy, C. M. Fauquet, D. H. L. Bishop, S. A. Ghabrial, A. W. Jarvis, G. P. Martelli, et al. (New York, NY: Academic Press), 835-849.

Faith, S. A., Sweet, T. J., Bailey, E., Booth, T., and Docherty, J. J. (2006). Resveratrol suppresses nuclear factor-kappaB in herpes simplex virus infected cells. Antiviral Res. 72, 242-251. doi:10.1016/j.antiviral.2006.06.011

Falzarano, D., De Wit, E., Martellaro, C., Callison, J., Munster, V. J., and Feldmann, H. (2013). Inhibition of novel $\beta$ coronavirus replication by a combination of interferon- $\alpha 2 b$ and ribavirin. Sci. Rep. 3, 1686. doi:10.1038/srep01686

Fensterl, V., and Sen, G. C. (2009). Interferons and viral infections. BioFactors 35, 14-20. doi:10.1002/biof.6

Filardo, S., Di Pietro, M., Mastromarino, P., and Sessa, R. (2020). Therapeutic potential of resveratrol against emerging respiratory viral infections. Pharmacol Ther. 214, 107613. doi:10.1016/j.pharmthera.2020.107613

Frabasile, S., Koishi, A. C., Kuczera, D., Silveira, G. F., Verri, W. A., Jr, Dos Santos, C. N. D., et al. (2017). The citrus flavanone naringenin impairs dengue virus replication in human cells. Sci. Rep. 7, 41864. doi:10.1038/srep41864

Gallagher, T. M., and Buchmeier, M. J. (2001). Coronavirus spike proteins in viral entry and pathogenesis. Virology 279, 371-374. doi:10.1006/viro. 2000.0757

Gentile, D., Patamia, V., Scala, A., Sciortino, M. T., Piperno, A., and Rescifina, A. (2020). Putative inhibitors of SARS-CoV-2 main protease from a library of marine natural products: a virtual screening and molecular modeling study. Mar. Drugs 18 (4), 225. doi:10.3390/md18040225

Godino, C., Scotti, A., Maugeri, N., Mancini, N., Fominskiy, E., Margonato, A., et al. (2020). Antithrombotic therapy in patients with COVID-19? -rationale and evidence. Int. J. Cardiol. 35 (9), 2698-2706. doi:10.1016/j.ijcard.2020. 09.064

Grundhoff, A., and Sullivan, C. S. (2011). Virus-encoded microRNAs. Virology 411, 325-343. doi:10.1016/j.virol.2011.01.002

Guan, W.-J., Ni, Z.-Y., Hu, Y., Liang, W.-H., Ou, C.-Q., He, J.-X., et al. (2020). Clinical characteristics of coronavirus disease 2019 in China. N. Engl. J. Med. 382 (18), 1708-1720. doi:10.1056/NEJMoa2002032

Hamada-Tsutsumi, S., Naito, Y., Sato, S., Takaoka, A., Kawashima, K., Isogawa, M., et al. (2019). The antiviral effects of human microRNA miR-302c-3p against hepatitis B virus infection. Aliment Pharmacol. Ther. 49, 1060-1070. doi:10. 1111/apt.15197
Hamasaki, K., Nakao, K., Matsumoto, K., Ichikawa, T., Ishikawa, H., and Eguchi, K. (2003). Short interfering RNA-directed inhibition of hepatitis B virus replication. FEBS Lett 543, 51-54. doi:10.1016/S0014-5793(03)00400-9

Hamre, D., and Procknow, J. J. (1966). A new virus isolated from the human respiratory tract. Proc. Soc. Exp. Biol. Med. 121, 190-193. doi:10.3181/ 00379727-121-30734

Hasan, M. M., Akter, R., Ullah, M., Abedin, M., Ullah, G., and Hossain, M. (2014). A computational approach for predicting role of human microRNAs in MERSCoV genome. Adv. bioinformatics 2014, 967946. doi:10.1155/2014/967946

Ho, B. C., Yu, I. S., Lu, L. F., Rudensky, A., Chen, H. Y., Tsai, C. W., et al. (2014). Inhibition of miR-146a prevents enterovirus-induced death by restoring the production of type I interferon. Nat. Commun. 5, 3344. doi:10.1038/ ncomms 4344

Ho, T.-Y., Wu, S.-L., Chen, J.-C., Li, C.-C., and Hsiang, C.-Y. (2007). Emodin blocks the SARS coronavirus spike protein and angiotensin-converting enzyme 2 interaction. Antiviral Res. 74, 92-101. doi:10.1016/j.antiviral.2006.04.014

Hoffmann, M., Kleine-Weber, H., Schroeder, S., Krüger, N., Herrler, T., Erichsen, S., et al. (2020). SARS-CoV-2 cell entry depends on ACE2 and TMPRSS2 and is blocked by a clinically proven protease inhibitor. Cell 181, 271-280. doi:10. 1016/j.cell.2020.02.052

Holshue, M. L., Debolt, C., Lindquist, S., Lofy, K. H., Wiesman, J., Bruce, H., et al. (2020). First case of 2019 novel coronavirus in the United States. N. Engl. J. Med. 382, 929-936. doi:10.1056/NEJMoa2001191

Huang, C., Wang, Y., Li, X., Ren, L., Zhao, J., Hu, Y., et al. (2020). Clinical features of patients infected with 2019 novel coronavirus in Wuhan, China. Lancet 395, 497-506. doi:10.1016/S0140-6736(20)30183-5

Huang, I.-C., Bailey, C. C., Weyer, J. L., Radoshitzky, S. R., Becker, M. M., Chiang, J. J., et al. (2011). Distinct patterns of IFITM-mediated restriction of filoviruses, SARS coronavirus, and influenza A virus. PLoS Pathog 7 (1), e1001258. doi:10. 1371/journal.ppat.1001258

ICTV (2009). Virus taxonomy: 2009 release. Available at: https://talk.ictvonline. org/ictv-reports/ictv_9th_report/negative-sense-rna-viruses-2011/w/negrna_ viruses/209/orthomyxoviridae (Accessed November 30, 2020).

Ivanov, K. A., Thiel, V., Dobbe, J. C., Van Der Meer, Y., Snijder, E. J., and Ziebuhr, J. (2004). Multiple enzymatic activities associated with severe acute respiratory syndrome coronavirus helicase. J. Virol. 78, 5619-5632. doi:10.1128/JVI.78.11. 5619-5632.2004

Izhaki, I. (2002). Emodin-a secondary metabolite with multiple ecological functions in higher plants. New Phytol. 155, 205-217. doi:10.1046/j.14698137.2002.00459.x

Jang, M., Park, Y.-I., Cha, Y.-E., Park, R., Namkoong, S., Lee, J. I., et al. (2020). Tea polyphenols EGCG and theaflavin inhibit the activity of SARS-CoV-2 3CLprotease in vitro. Evid. Based Complement. Alternat. Med. 2020, 5630838. doi:10.1155/2020/5630838

Ji, H. F., Li, X. J., and Zhang, H. Y. (2009). Natural products and drug discovery. Can thousands of years of ancient medical knowledge lead us to new and powerful drug combinations in the fight against cancer and dementia? $E M B O$ Rep. 10, 194-200. doi:10.1038/embor.2009.12

Jo, S., Kim, H., Kim, S., Shin, D. H., and Kim, M. S. (2019). Characteristics of flavonoids as potent MERS-CoV 3C-like protease inhibitors. Chem. Biol. Drug Des. 94, 2023-2030. doi:10.1111/cbdd.13604

Jo, S., Kim, S., Kim, D. Y., Kim, M.-S., and Shin, D. H. (2020a). Flavonoids with inhibitory activity against SARS-CoV-2 3CLpro. J. Enzyme Inhib. Med. Chem. 35, 1539-1544. doi:10.1080/14756366.2019.169048010.1080/14756366.2020. 1801672

Jo, S., Kim, S., Shin, D. H., and Kim, M.-S. (2020b). Inhibition of SARS-CoV 3CL protease by flavonoids. J. Enzyme Inhib. Med. Chem. 35, 145-151. doi:10.1080/ 14756366.2019.1690480

Jopling, C. L., Yi, M., Lancaster, A. M., Lemon, S. M., and Sarnow, P. (2005). Modulation of hepatitis $\mathrm{C}$ virus RNA abundance by a liver-specific microRNA. Science 309, 1577-1581. doi:10.1126/science.1113329

Kalhori, M. R., Arefian, E., Atanaki, F. F., Kavousi, K., and Soleimani, M. (2020). miR-548x and miR-4698 controlled cell proliferation by affecting the PI3K/ AKT signaling pathway in glioblastoma cell lines. Sci. Rep. 10, 1-12. doi:10. 1038/s41598-020-57588-5

Keum, Y.-S., Lee, J. M., Yu, M.-S., Chin, Y.-W., and Jeong, Y.-J. (2013). Inhibition of SARS coronavirus helicase by baicalein. Bull Korean Chem. Soc. 34, 3187-3188. doi:10.5012/bkcs.2013.34.11.3187 
Khalid, M., Al Rabiah, F., Khan, B., Al Mobeireek, A., Butt, T. S., and Al Mutairy, E. (2015). Ribavirin and interferon- $\alpha 2 b$ as primary and preventive treatment for Middle East respiratory syndrome coronavirus: a preliminary report of two cases. Antivir. Ther. (Lond) 20, 87-91. doi:10.3851/IMP2792

Khan, M. A., Sany, M. R. U., Islam, M. S., and Islam, A. (2020). Epigenetic regulator miRNA pattern differences among SARS-CoV, SARS-CoV-2, and SARS-CoV2 World-Wide isolates delineated the mystery behind the epic pathogenicity and distinct clinical characteristics of pandemic COVID-19. Front. Genet. 11, 765. doi:10.3389/fgene.2020.00765

Kim, D. E., Min, J. S., Jang, M. S., Lee, J. Y., Shin, Y. S., Park, C. M., et al. (2019). Natural bis-benzylisoquinoline alkaloids-tetrandrine, fangchinoline, and cepharanthine, inhibit human coronavirus OC43 infection of MRC-5 human lung cells. Biomolecules 9, 696. doi:10. 3390/biom 9110696

Kim, D. W., Seo, K. H., Curtis-Long, M. J., Oh, K. Y., Oh, J.-W., et al. (2014). Phenolic phytochemical displaying SARS-CoV papain-like protease inhibition from the seeds of Psoralea corylifolia. J. Enzyme Inhib. Med. Chem. 29, 59-63. doi:10.1371/journal.ppat.100301810.3109/14756366.2012.753591

Kincaid, R. P., and Sullivan, C. S. (2012). Virus-encoded microRNAs: an overview and a look to the future. PLoS Pathog. 8, e1003018. doi:10.1371/journal.ppat. 1003018

King, A. M., Adams, M. J., Carstens, E. B., and Lefkowitz, E. J. (2012). "Virus taxonomy," in Ninth report of the international committee on Taxonomy of viruses (London, United Kingdom: Elsevier Academic Press), 486-487.

Kuo, L., Godeke, G.-J., Raamsman, M. J., Masters, P. S., and Rottier, P. J. (2000). Retargeting of coronavirus by substitution of the spike glycoprotein ectodomain: crossing the host cell species barrier. J. Virol. 74, 1393-1406. doi:10.1128/JVI.74.3.1393-1406.2000

Lai, F. W., Stephenson, K. B., Mahony, J., and Lichty, B. D. (2014). Human coronavirus OC43 nucleocapsid protein binds microRNA 9 and potentiates NF-kB activation. J. Virol. 88, 54-65. doi:10.1128/JVI.02678-13

Lai, M. M., and Cavanagh, D. (1997). The molecular biology of coronaviruses. Adv. Virus Res. 48, 1-100. doi:10.1016/S0065-3527(08)60286-9

Lai, M. M. (1990). Coronavirus: organization, replication and expression of genome. Аnnu. Rev. Microbiol. 44, 303. doi:10.1146/annurev.mi.44.100190. 001511

Lecellier, C. H., Dunoyer, P., Arar, K., Lehmann-Che, J., Eyquem, S., Himber, C., et al. (2005). A cellular microRNA mediates antiviral defense in human cells. Science 308, 557-560. doi:10.1126/science.1108784

Lei, J., Kusov, Y., and Hilgenfeld, R. (2018). Nsp3 of coronaviruses: structures and functions of a large multi-domain protein. Antiviral Res. 149, 58-74. doi:10. 1016/j.antiviral.2017.11.001

Leon-Icaza, S. A., Zeng, M., and Rosas-Taraco, A. G. (2019). MicroRNAs in viral acute respiratory infections: immune regulation, biomarkers, therapy, and vaccines. ExRNA 1 (1), 1. doi:10.1186/s41544-018-0004-7

Li, B.-J., Tang, Q., Cheng, D., Qin, C., Xie, F. Y., Wei, Q., et al. (2005a). Using siRNA in prophylactic and therapeutic regimens against SARS coronavirus in Rhesus macaque. Nat. Med. 11, 944-951. doi:10.1038/nm1280

Li, F. (2016). Structure, function, and evolution of coronavirus spike proteins. Annu. Rev. Virol. 3, 237-261. doi:10.1146/annurev-virology-110615-042301

Li, G., and De Clercq, E. (2020). Therapeutic options for the 2019 novel coronavirus (2019-nCoV. Nat. Rev. Drug. Discov. 19, 149-150. doi:10.1038/ d41573-020-00016-0

Li, T., Zhang, Y., Fu, L., Yu, C., Li, X., Li, Y., et al. (2005b). SiRNA targeting the leader sequence of SARS-CoV inhibits virus replication. Gene Ther. 12, 751-761. doi:10.1038/sj.gt.3302479

Liang, X., and Li, Z.-Y. (2010). Ion channels as antivirus targets. Virol. Sin. 25, 267-280. doi:10.1007/s12250-010-3136-y

Lin, C.-W., Tsai, F.-J., Wan, L., Lai, C.-C., Lin, K.-H., Hsieh, T.-H., et al. (2005). Binding interaction of SARS coronavirus $3 \mathrm{CL}$ (pro) protease with vacuolar- $\mathrm{H}+$ ATPase G1 subunit. FEBS Lett. 579, 6089-6094. doi:10.1016/j.febslet.2005. 09.075

Lin, S.-C., Ho, C.-T., Chuo, W.-H., Li, S., Wang, T. T., and Lin, C.-C. (2017). Effective inhibition of MERS-CoV infection by resveratrol. BMC Infect. Dis. 17, 144. doi:10.1186/s12879-017-2253-8

Liu, C., Chen, Z., Hu, Y., Ji, H., Yu, D., Shen, W., et al. (2018). Complemented palindromic small RNAs first discovered from SARS coronavirus. Genes 9, 442. doi:10.3390/genes 9090442
Liu, C., Liang, Z., and Kong, X. (2017). Efficacy analysis of combinatorial siRNAs against HIV derived from one double hairpin RNA precursor. Front. Microbiol. 8, 1651. doi:10.3389/fmicb.2017.01651

Liu, C., Zhou, Q., Li, Y., Garner, L. V., Watkins, S. P., Carter, L. J., et al. (2020). Research and development on therapeutic agents and vaccines for COVID-19 and related human coronavirus diseases. ACS Cent. Sci. 6, 315-331. doi:10. 1021/acscentsci.0c00272

Liu, D., Yuan, Q., and Liao, Y. (2007). Coronavirus envelope protein: a small membrane protein with multiple functions. Cell Mol. Life Sci. 64, 2043-2048. doi:10.1007/s00018-007-7103-1

Lu, A., Zhang, H., Zhang, X., Wang, H., Hu, Q., Shen, L., et al. (2004). Attenuation of SARS coronavirus by a short hairpin RNA expression plasmid targeting RNA-dependent RNA polymerase. Virology 324, 84-89. doi:10.1016/j.virol. 2004.03.031

Lu, C.-Y., Huang, H.-Y., Yang, T.-H., Chang, L.-Y., Lee, C.-Y., and Huang, L.-M. (2008). siRNA silencing of angiotensin-converting enzyme 2 reduced severe acute respiratory syndrome-associated coronavirus replications in Vero E6 cells. Eur. J. Clin. Microbiol. Infect. Dis. 27, 709-715. doi:10.1007/s10096-0080495-5

Ma, Y., Wang, C., Xue, M., Fu, F., Zhang, X., Li, L., et al. (2018). The coronavirus transmissible gastroenteritis virus evades the type I interferon response through IRE1 $\alpha$-mediated manipulation of the microRNA miR-30a-5p/SOCS1/3 axis. J. Virol. 92, e00728-e00718. doi:10.1128/JVI.00728-18

Mahase, E. (2020). Coronavirus covid-19 has killed more people than SARS and MERS combined, despite lower case fatality rate. BMJ 368, m641. doi:10.1136/ bmj.m641

Mallick, B., Ghosh, Z., and Chakrabarti, J. (2009). MicroRNome analysis unravels the molecular basis of SARS infection in bronchoalveolar stem cells. PLoS One 4 (11), e7837. doi:10.1371/journal.pone.0007837

Maurya, V. K., Kumar, S., Prasad, A. K., Bhatt, M. L. B., and Saxena, S. K. (2020). Structure-based drug designing for potential antiviral activity of selected natural products from Ayurveda against SARS-CoV-2 spike glycoprotein and its cellular receptor. Virusdisease 31, 179-193. doi:10.1007/s13337-020-00598-8

Mcintosh, K., Kapikian, A. Z., Turner, H. C., Hartley, J. W., Parrott, R. H., and Chanock, R. M. (1970). Seroepidemiologic studies of coronavirus infection in adults and children. Am. J. Epidemiol. 91, 585-592. doi:10.1093/oxfordjournals. aje.a121171

Mcintosh, K., and Peiris, J. (2009). "Coronaviruses," in Clinical virology. 3rd Edn. (Washington, DC: American Society of Microbiology Press), 1155-1171. doi:10.1128/9781555815981.ch51

Miknis, Z. J., Donaldson, E. F., Umland, T. C., Rimmer, R. A., Baric, R. S., and Schultz, L. W. (2009). Severe acute respiratory syndrome coronavirus nsp9 dimerization is essential for efficient viral growth. J. Virol. 83, 3007-3018. doi:10.1128/JVI.01505-08

Monto, A. S. (1974). Medical reviews. Coronaviruses. Yale J. Biol. Med. 47 (4), 234-251.

Moore, M. J., Dorfman, T., Li, W., Wong, S. K., Li, Y., Kuhn, J. H., et al. (2004). Retroviruses pseudotyped with the severe acute respiratory syndrome coronavirus spike protein efficiently infect cells expressing angiotensinconverting enzyme 2. J. Virol. 78, 10628-10635. doi:10.1128/JVI.78.19. 10628-10635.2004

Mu, J., Xu, J., Zhang, L., Shu, T., Wu, D., Huang, M., et al. (2020). SARS-CoV-2encoded nucleocapsid protein acts as a viral suppressor of RNA interference in cells. Sci. China Life Sci. 63, 1-4. doi:10.1007/s11427-020-1692-1

Muramatsu, T., Takemoto, C., Kim, Y.-T., Wang, H., Nishii, W., Terada, T., et al. (2016). SARS-CoV 3CL protease cleaves its C-terminal autoprocessing site by novel subsite cooperativity. Proc. Natl. Acad. Sci. U.S.A 113, 12997-13002. doi:10.1073/pnas.1601327113

Nal, B., Chan, C., Kien, F., Siu, L., Tse, J., Chu, K., et al. (2005). Differential maturation and subcellular localization of severe acute respiratory syndrome coronavirus surface proteins S, M and E. J. Gen. Virol. 86, 1423-1434. doi:10. 1099/vir.0.80671-0

Nguyen, T. T. H., Woo, H.-J., Kang, H.-K., Kim, Y.-M., Kim, D.-W., Ahn, S.-A., et al. (2012). Flavonoid-mediated inhibition of SARS coronavirus 3C-like protease expressed in Pichia pastoris. Biotechnol. Lett. 34, 831-838. doi:10. 1007/s10529-011-0845-8

Ni, B., Shi, X., Li, Y., Gao, W., Wang, X., and Wu, Y. (2005). Inhibition of replication and infection of severe acute respiratory syndrome-associated 
coronavirus with plasmid-mediated interference RNA. Antivir. Ther. (Lond) 10, 527-533.

Opstelten, D. J., Raamsman, M., Wolfs, K., Horzinek, M. C., and Rottier, P. (1995). Envelope glycoprotein interactions in coronavirus assembly. J. Cell Biol. 131, 339-349. doi:10.1083/jcb.131.2.339

Pafumi, I., Festa, M., Papacci, F., Lagostena, L., Giunta, C., Gutla, V., et al. (2017). Naringenin impairs two-pore channel 2 activity and inhibits VEGF-induced angiogenesis. Sci. Rep. 7, 1-11. doi:10.1038/s41598-017-04974-1

Pan, B., Fang, S., Zhang, J., Pan, Y., Liu, H., Wang, Y., et al. (2020). Chinese herbal compounds against SARS-CoV-2: puerarin and quercetin impair the binding of viral S-protein to ACE2 receptor. Comput. Struct. Biotechnol. J. 18, 3518-3527. doi:10.1016/j.csbj.2020.11.010

Park, J.-Y., Jeong, H. J., Kim, J. H., Kim, Y. M., Park, S.-J., Kim, D., et al. (2012a). Diarylheptanoids from Alnus japonica inhibit papain-like protease of severe acute respiratory syndrome coronavirus. Biol. Pharm. Bull. 35, 2036. doi:10. 1248/bpb.b12-00623

Park, J.-Y., Kim, J. H., Kim, Y. M., Jeong, H. J., Kim, D. W., Park, K. H., et al. (2012b). Tanshinones as selective and slow-binding inhibitors for SARS-CoV cysteine proteases. Bioorg. Med. Chem. 20 (19), 5928-5935. doi:10.1016/j.bmc. 2012.07.038

Park, J.-Y., Ko, J.-A., Kim, D. W., Kim, Y. M., Kwon, H.-J., Jeong, H. J., et al. (2016). Chalcones isolated from Angelica keiskei inhibit cysteine proteases of SARS-CoV. J. Enzyme Inhib. Med. Chem. 31 (1), 23-30. doi:10.3109/14756366.2014.1003215

Park, J.-Y., Yuk, H. J., Ryu, H. W., Lim, S. H., Kim, K. S., Park, K. H., et al. (2017). Evaluation of polyphenols from Broussonetia papyrifera as coronavirus protease inhibitors. J. Enzyme Inhib. Med. Chem. 32, 504-512. doi:10.1080/ 14756366.2016.1265519

Peiris, J. S. M., Chu, C.-M., Cheng, V. C.-C., Chan, K., Hung, I., Poon, L. L., et al. (2003). Clinical progression and viral load in a community outbreak of coronavirus-associated SARS pneumonia: a prospective study. Lancet 361, 1767-1772. doi:10.1016/s0140-6736(03)13412-5

Prajapat, M., Sarma, P., Shekhar, N., Avti, P., Sinha, S., Kaur, H., et al. (2020). Drug targets for corona virus: a systematic review. Indian J. Pharmacol. 52 (1), 56-65. doi:10.4103/ijp.IJP_115_20

Pyrc, K., Berkhout, B., and Van Der Hoek, L. (2007). Antiviral strategies against human coronaviruses. Infect. Disord. Drug. Targets 7, 59-66. doi:10.2174/ 187152607780090757

Rahman, N., Basharat, Z., Yousuf, M., Castaldo, G., Rastrelli, L., and Khan, H. (2020). Virtual screening of natural products against type II Transmembrane serine protease (TMPRSS2), the priming agent of coronavirus 2 (SARS-CoV-2). Molecules 25 (10), 2271. doi:10.3390/molecules 25102271

Raj, V. S., Mou, H., Smits, S. L., Dekkers, D. H., Müller, M. A., Dijkman, R., et al. (2013). Dipeptidyl peptidase 4 is a functional receptor for the emerging human coronavirus-EMC. Nature 495, 251-254. doi:10.1038/nature12005

Ren, L.-L., Wang, Y.-M., Wu, Z.-Q., Xiang, Z.-C., Guo, L., Xu, T., et al. (2020). Identification of a novel coronavirus causing severe pneumonia in human: a descriptive study. Chin. Med. J. (Engl) 133 (9), 1015-1024. doi:10.1097/CM9. 0000000000000722

Ricagno, S., Egloff, M.-P., Ulferts, R., Coutard, B., Nurizzo, D., Campanacci, V., et al. (2006). Crystal structure and mechanistic determinants of SARS coronavirus nonstructural protein 15 define an endoribonuclease family. Proc. Natl. Acad. Sci. U.S.A. 103, 11892-11897. doi:10.1073/pnas.0601708103

Russell, C. D., Millar, J. E., and Baillie, J. K. (2020). Clinical evidence does not support corticosteroid treatment for 2019-nCoV lung injury. Lancet 395, 473-475. doi:10.1016/S0140-6736(20)30317-2

Sadler, A. J., and Williams, B. R. (2008). Interferon-inducible antiviral effectors. Nat. Rev. Immunol. 8, 559-568. doi:10.1038/nri2314

Samuel, C. E. (2001). Antiviral actions of interferons. Clin Microbiol Rev 14, 778-809. doi:10.1128/CMR.14.4.778-809.2001

Sanghvi, V. R., and Steel, L. F. (2012). RNA silencing as a cellular defense against HIV-1 infection: progress and issues. FASEB J. 26, 3937-3945. doi:10.1096/fj. 12-210765

Sawicki, S. G., Sawicki, D. L., Younker, D., Meyer, Y., Thiel, V., Stokes, H., et al. (2005). Functional and genetic analysis of coronavirus replicase-transcriptase proteins. PLoS Pathog. 1 (4), e39. doi:10.1371/journal.ppat.0010039

Sayed, A. M., Alhadrami, H. A., El-Gendy, A. O., Shamikh, Y. I., Belbahri, L., Hassan, H. M., et al. (2020). Microbial natural products as potential inhibitors of SARS-CoV-2 main protease (M(pro)). Microorganisms 8 (7), 970. doi:10. 3390/microorganisms 8070970

Schwarz, S., Sauter, D., Wang, K., Zhang, R., Sun, B., Karioti, A., et al. (2014). Kaempferol derivatives as antiviral drugs against the $3 \mathrm{a}$ channel protein of coronavirus. Planta Med. 80, 177-182. doi:10.1055/s-0033-1360277

Schwarz, S., Wang, K., Yu, W., Sun, B., and Schwarz, W. (2011). Emodin inhibits current through SARS-associated coronavirus 3a protein. Antiviral Res. 90, 64-69. doi:10.1016/j.antiviral.2011.02.008

Shahid, I., Almalki, W. H., Alrabia, M. W., Mukhtar, M. H., Almalki, S. S. R., Alkahtani, S. A., et al. (2017). In vitro inhibitory analysis of consensus siRNAs against NS3 gene of hepatitis C virus 1a genotype. Asian Pac. J. Trop. Med. 10, 701-709. doi:10.1016/j.apjtm.2017.07.011

Sharma, N., Verma, R., Kumawat, K. L., Basu, A., and Singh, S. K. (2015). miR-146a suppresses cellular immune response during Japanese encephalitis virus JaOArS982 strain infection in human microglial cells. J. Neuroinflammation 12, 30. doi:10.1186/s12974-015-0249-0

Shim, B.-S., Wu, W., Kyriakis, C. S., Bakre, A., Jorquera, P. A., Perwitasari, O., et al. (2016). MicroRNA-555 has potent antiviral properties against poliovirus. J. Gen. Virol. 97, 659-668. doi:10.1099/jgv.0.000372

Silveira, D., Prieto-Garcia, J. M., Boylan, F., Estrada, O., Fonseca-Bazzo, Y. M., Jamal, C. M., et al. (2020). COVID-19: is there evidence for the use of herbal medicines as adjuvant symptomatic therapy? Front. Pharmacol. 11, 581840. doi:10.3389/fphar.2020.581840

Siu, K.-L., Kok, K.-H., Ng, M.-H. J., Poon, V. K., Yuen, K.-Y., Zheng, B.-J., et al. (2009). Severe acute respiratory syndrome coronavirus M protein inhibits type I interferon production by impeding the formation of TRAF3.TANK.TBK1/ IKKepsilon complex. J. Biol. Chem. 284, 16202-16209. doi:10.1074/jbc.M109. 008227

Sohrab, S. S., El-Kafrawy, S. A., Mirza, Z., Kamal, M. A., and Azhar, E. I. (2018). Design and delivery of therapeutic siRNAs: application to MERS-coronavirus. Curr. Pharm. Des. 24, 62-77. doi:10.2174/1381612823666171109112307

Song, J., Zhang, L., Xu, Y., Yang, D., Yang, S., Zhang, W., et al. (2020). The comprehensive study on the therapeutic effects of baicalein for the treatment of COVID-19 in vivo and in vitro. Biochem. Pharmacol. 183, 114302. doi:10.1016/ j.bcp.2020.114302

Su, B., Wang, Y., Zhou, R., Jiang, T., Zhang, H., Li, Z., et al. (2019). Efficacy and tolerability of lopinavir/ritonavir- and efavirenz-based initial antiretroviral therapy in HIV-1-Infected patients in a tertiary care hospital in beijing, China. Front. Pharmacol. 10, 1472. doi:10.3389/fphar.2019.01472

Su, H.-X., Yao, S., Zhao, W.-F., Li, M.-J., Liu, J., Shang, W.-J., et al. (2020). AntiSARS-CoV-2 activities in vitro of Shuanghuanglian preparations and bioactive ingredients. Acta. Pharmacol. Sin. 41, 1167-1177. doi:10.1038/s41401-0200483-6

Taning, C. N., Christiaens, O., Li, X., Swevers, L., Casteels, H., Maes, M., et al. (2018). Engineered flock house virus for targeted gene suppression through RNAi in fruit flies (Drosophila melanogaster) in vitro and in vivo. Front. Physiol. 9, 805. doi:10.3389/fphys.2018.00805

Tanner, J. A., Watt, R. M., Chai, Y.-B., Lu, L.-Y., Lin, M. C., Peiris, J. M., et al. (2003). The severe acute respiratory syndrome (SARS) coronavirus NTPase/ helicase belongs to a distinct class of $5^{\prime}$ to $3^{\prime}$ viral helicases. J. Biol. Chem. 278, 39578-39582. doi:10.1074/jbc.C300328200

Tanner, J. A., Zheng, B.-J., Zhou, J., Watt, R. M., Jiang, J.-Q., Wong, K.-L., et al. (2005). The adamantane-derived bananins are potent inhibitors of the helicase activities and replication of SARS coronavirus. Chem. Biol. 12, 303-311. doi:10. 1016/j.chembiol.2005.01.006

Tapas, A. R., Sakarkar, D., and Kakde, R. (2008). Flavonoids as nutraceuticals: a review. Trop J. Pharm. Res. 7, 1089-1099. doi:10.4314/tjpr.v7i3.14693

Taxman, D. J., Livingstone, L. R., Zhang, J., Conti, B. J., Iocca, H. A., Williams, K. L., et al. (2006). Criteria for effective design, construction, and gene knockdown by shRNA vectors. BMC Biotechnol. 6, 7. doi:10.1186/1472-6750-6-7

Te Velthuis, A. J., Van Den Worm, S. H., and Snijder, E. J. (2012). The SARScoronavirus nsp7+ nsp8 complex is a unique multimeric RNA polymerase capable of both de novo initiation and primer extension. Nucleic Acids Res 40, 1737-1747. doi:10.1093/nar/gkr893

Thiel, V., Ivanov, K. A., Putics, A., Hertzig, T., Schelle, B., Bayer, S., et al. (2003). Mechanisms and enzymes involved in SARS coronavirus genome expression. J. Gen. Virol. 84, 2305-2315. doi:10.1099/vir.0.19424-0 
Uzunova, K., Filipova, E., Pavlova, V., and Vekov, T. (2020). Insights into antiviral mechanisms of remdesivir, lopinavir/ritonavir and chloroquine/ hydroxychloroquine affecting the new SARS-CoV-2. Biomed. Pharmacother. 131, 110668. doi:10.1016/j.biopha.2020.110668

Vazquez, F. (2006). Arabidopsis endogenous small RNAs: highways and byways. Trends Plant Sci. 11, 460-468. doi:10.1016/j.tplants.2006.07.006

Wang, J., Qi, H., Bao, L., Li, F., and Shi, Y. (2020). A contingency plan for the management of the 2019 novel coronavirus outbreak in neonatal intensive care units. Lancet Child Adolesc. Health 4 (4), 258-259. doi:10.1016/S2352-4642(20) 30040-7

Wang, M., Cao, R., Zhang, L., Yang, X., Liu, J., Xu, M., et al. (2020). Remdesivir and chloroquine effectively inhibit the recently emerged novel coronavirus (2019$\mathrm{nCoV})$ in vitro. Cell Res. 30, 269-271. doi:10.1038/s41422-020-0282-0

Wang, X., Cao, R., Zhang, H., Liu, J., Xu, M., Hu, H., et al. (2020). The antiinfluenza virus drug, arbidol is an efficient inhibitor of SARS-CoV-2 in vitro. Cell Discov. 6, 28. doi:10.1038/s41421-020-0169-8

Wang, Y., Mao, J., Wang, G., Qiu, Z., Yao, Q., and Chen, K. (2020). Human SARSCoV-2 has evolved to reduce CG dinucleotide in its open reading frames. Res. Squ. 10, 12331. doi:10.1038/s41598-020-69342-y

Wang, Z., Ren, L., Zhao, X., Hung, T., Meng, A., Wang, J., et al. (2004). Inhibition of severe acute respiratory syndrome virus replication by small interfering RNAs in mammalian cells. J. Virol. 78, 7523-7527. doi:10.1128/JVI.78.14.7523-7527. 2004

Woo, P. C., Huang, Y., Lau, S. K., and Yuen, K.-Y. (2010). Coronavirus genomics and bioinformatics analysis. viruses 2, 1804-1820. doi:10.3390/v2081803

Wrensch, F., Winkler, M., and Pöhlmann, S. (2014). IFITM proteins inhibit entry driven by the MERS-coronavirus spike protein: evidence for cholesterolindependent mechanisms. Viruses 6, 3683-3698. doi:10.3390/v6093683

Wu, C.-H., Yeh, S.-H., Tsay, Y.-G., Shieh, Y.-H., Kao, C.-L., Chen, Y.-S., et al. (2009). Glycogen synthase kinase-3 regulates the phosphorylation of severe acute respiratory syndrome coronavirus nucleocapsid protein and viral replication. J. Biol. Chem. 284, 5229-5239. doi:10.1074/jbc.M805747200

Wu, C.-J., and Chan, Y.-L. (2006). Antiviral applications of RNAi for coronavirus. Expert Opin. Investig. Drugs 15, 89-97. doi:10.1517/13543784.15.2.89

Wu, F., Zhao, S., Yu, B., Chen, Y. M., Wang, W., Song, Z. G., et al. (2020). A new coronavirus associated with human respiratory disease in China. Nature 579, 265-269. doi:10.1038/s41586-020-2008-3

Wu, S., He, L., Li, Y., Wang, T., Feng, L., Jiang, L., et al. (2013). MiR-146a facilitates replication of dengue virus by dampening interferon induction by targeting TRAF6. J. Infect 67, 329-341. doi:10.1016/j.jinf.2013.05.003

Xu, K., Chen, Y., Yuan, J., Yi, P., Ding, C., Wu, W., et al. (2020a). Clinical efficacy of arbidol in patients with 2019 novel coronavirus-infected pneumonia: a retrospective cohort study. SSRN Elect. J. 2020, 3542148. doi:10.2139/ssrn.3542148

Xu, X., Chen, P., Wang, J., Feng, J., Zhou, H., Li, X., et al. (2020b). Evolution of the novel coronavirus from the ongoing Wuhan outbreak and modeling of its spike protein for risk of human transmission. Sci. China Life Sci. 63, 457-460. doi:10. 1007/s11427-020-1637-5

Xu, Z., Peng, C., Shi, Y., Zhu, Z., Mu, K., Wang, X., et al. (2020c). Nelfinavir was predicted to be a potential inhibitor of 2019-nCov main protease by an integrative approach combining homology modelling, molecular docking and binding free energy calculation. BioRxiv 2020, 921627. doi:10.1101/ 2020.01.27.921627

Yeung, A. W. K., Aggarwal, B. B., Balacheva, A., Barreca, D., Battino, M., Belwal, T., et al. (2019). Resveratrol, a popular dietary supplement for human and animal health: quantitative research literature analysis. Animal Sci. Papers Reports 36 (4), 345-358.

Yi, S., De Hua, Y., Xiong, J., Jie, J., Huang, B., and Jin, Y. X. (2005). Inhibition of genes expression of SARS coronavirus by synthetic small interfering RNAs. Cell Res. 15, 193-200. doi:10.1038/sj.cr.7290286
Yu, M.-S., Lee, J., Lee, J. M., Kim, Y., Chin, Y.-W., Jee, J.-G., et al. (2012). Identification of myricetin and scutellarein as novel chemical inhibitors of the SARS coronavirus helicase, nsP13. Bioorg. Med. Chem. Lett. 22, 4049-4054. doi:10.1016/j.bmcl.2012.04.081

Zang, N., Xie, X., Deng, Y., Wu, S., Wang, L., Peng, C., et al. (2011). Resveratrolmediated gamma interferon reduction prevents airway inflammation and airway hyperresponsiveness in respiratory syncytial virus-infected immunocompromised mice. J. Virol. 85, 13061-13068. doi:10.1128/JVI. 05869-11

Zhai, A., Qian, J., Kao, W., Li, A., Li, Y., He, J., et al. (2013). Borna disease virus encoded phosphoprotein inhibits host innate immunity by regulating miR-155. Antiviral Res. 98, 66-75. doi:10.1016/j.antiviral.2013.02.009

Zhang, H., Li, Z., Li, Y., Liu, Y., Liu, J., Li, X., et al. (2013). A computational method for predicting regulation of human microRNAs on the influenza virus genome. BMC Syst. Biol. 7 (S2), S3. doi:10.1186/1752-0509-7-S2-S3

Zhang, H., Penninger, J. M., Li, Y., Zhong, N., and Slutsky, A. S. (2020a). Angiotensin-converting enzyme 2 (ACE2) as a SARS-CoV-2 receptor: molecular mechanisms and potential therapeutic target. Intensive Care Med. 46 (4), 586-590. doi:10.1007/s00134-020-05985-9

Zhang, J., Zhou, L., Yang, Y., Peng, W., Wang, W., and Chen, X. (2020b). Therapeutic and triage strategies for 2019 novel coronavirus disease in fever clinics. Lancet Respir. Med. 8 (3), el1-e12. doi:10.1016/S2213-2600(20)30071-0

Zhang, Y., Li, T., Fu, L., Yu, C., Li, Y., Xu, X., et al. (2004). Silencing SARS-CoV Spike protein expression in cultured cells by RNA interference. FEBS Lett. 560, 141-146. doi:10.1016/S0014-5793(04)00087-0

Zhao, G., Shi, S.-Q., Yang, Y., and Peng, J.-P. (2006). M and N proteins of SARS coronavirus induce apoptosis in HPF cells. Cell Biol. Toxicol. 22, 313-322. doi:10.1007/s10565-006-0077-1

Zhao, X., Guo, F., Liu, F., Cuconati, A., Chang, J., Block, T. M., et al. (2014). Interferon induction of IFITM proteins promotes infection by human coronavirus OC43. Proc. Natl. Acad. Sci. U.S.A 111, 6756-6761. doi:10.1073/ pnas. 1320856111

Zheng, B., He, M.-L., Wong, K.-L., Lum, C. T., Poon, L. L., Peng, Y., et al. (2004). Potent inhibition of SARS-associated coronavirus (SCOV) infection and replication by type I interferons (IFN- $\alpha / \beta)$ but not by type II interferon (IFN- $\gamma$ ). J. Interferon Cytokine Res. 24, 388-390. doi:10.1089/ 1079990041535610

Zhou, P., Yang, X.-L., Wang, X.-G., Hu, B., Zhang, L., Zhang, W., et al. (2020). Discovery of a novel coronavirus associated with the recent pneumonia outbreak in humans and its potential bat origin. BioRxiv 2020, 914952. doi:10.1101/2020.01.22.914952

Ziebuhr, J. (2005). The coronavirus replicase. Coronavirus Rep. Rev. Gen. 287, 57-94. doi:10.1007/3-540-26765-4_3

Zimmermann, P., and Curtis, N. (2020). Coronavirus infections in children including COVID-19: an overview of the epidemiology, clinical features, diagnosis, treatment and prevention options in children. Pediatr. Infect. Dis. J. 39 (5), 355-368. doi:10.1097/INF.0000000000002660

Conflict of Interest: The authors declare that the research was conducted in the absence of any commercial or financial relationships that could be construed as a potential conflict of interest.

Copyright (® 2021 Kalhori, Saadatpour, Arefian, Soleimani, Farzaei, Aneva and Echeverria. This is an open-access article distributed under the terms of the Creative Commons Attribution License (CC BY). The use, distribution or reproduction in other forums is permitted, provided the original author $(s)$ and the copyright owner $(s)$ are credited and that the original publication in this journal is cited, in accordance with accepted academic practice. No use, distribution or reproduction is permitted which does not comply with these terms. 